Cronfa - Swansea University Open Access Repository

This is an author produced version of a paper published in :

Journal of Urban History

Cronfa URL for this paper:

http://cronfa.swan.ac.uk/Record/cronfa30502

\title{
Paper:
}

Chronopoulos, T. (in press). Police Misconduct, Community Opposition, and Urban Governance in New York City, 1945-1965. Journal of Urban History

http://dx.doi.org/10.1177/0096144215574695

This article is brought to you by Swansea University. Any person downloading material is agreeing to abide by the terms of the repository licence. Authors are personally responsible for adhering to publisher restrictions or conditions. When uploading content they are required to comply with their publisher agreement and the SHERPA RoMEO database to judge whether or not it is copyright safe to add this version of the paper to this repository. http://www.swansea.ac.uk/iss/researchsupport/cronfa-support/ 


\section{Police Misconduct, Community Opposition, and Urban Governance in New York City, 1945-1965}

Journal of Urban History

I-26

(C) 2015 SAGE Publications

Reprints and permissions: sagepub.com/journalsPermissions.nav DOI: I0.I I77/0096|442 I5574695 juh.sagepub.com

\title{
Themis Chronopoulos'
}

\begin{abstract}
In the post-World War II period, the police department emerged as one of the most problematic municipal agencies in New York City. Patrolmen and their superiors did not pay much attention to crime; instead they looked the other way, received payoffs from organized crime, performed haphazardly, and tolerated conditions that were unacceptable in a modern city with global ambitions. At the same time, patrolmen demanded deference and respect from African American civilians and routinely demeaned and brutalized individuals who appeared to be challenging their authority. The antagonism between African Americans and the New York Police Department (NYPD) intensified as local and national black freedom organizations paid more attention to police behavior and made police reform one of their main goals.
\end{abstract}

\section{Keywords}

black freedom movement, New York Police Department, police misconduct, urban governance, New York City

\section{Article}

In July of 1964, the first major uprising of the 1960s occurred in the African American neighborhoods of Harlem and Bedford-Stuyvesant in New York City. It grew out of a rally organized by the Congress of Racial Equality (CORE) in Harlem after a black junior high school student was shot and killed by a white police lieutenant in the Upper East Side. Protesters from the rally marched to the 28th precinct on West 123rd Street (Figure 1) and after police tried to push them to the sidewalk across the street they started chanting "Murder, murder, murder" and singing "We Shall Not Be Moved, Murphy [the police commissioner] is a bastard, he must be removed." After arrests, scuffles, and a counteroffensive, the police managed to clear the street. However, the crowd grew to more than a thousand on Seventh Avenue and West 123rd Street. With reinforcements, the police began to charge through the crowd, but many of the people who dispersed were joined by others who activated fire alarms, set small fires, destroyed stores, and threw objects from rooftops at the police. The insurrection lasted for about a week and spread to

\footnotetext{
'Department of American Studies, University of East Anglia, Norwich, United Kingdom
}

\section{Corresponding Author:}

Themis Chronopoulos, Department of American Studies, University of East Anglia, Norwich Research Park, Norwich NR4 7TJ, United Kingdom.

Email: T.Chronopoulos@uea.ac.uk 


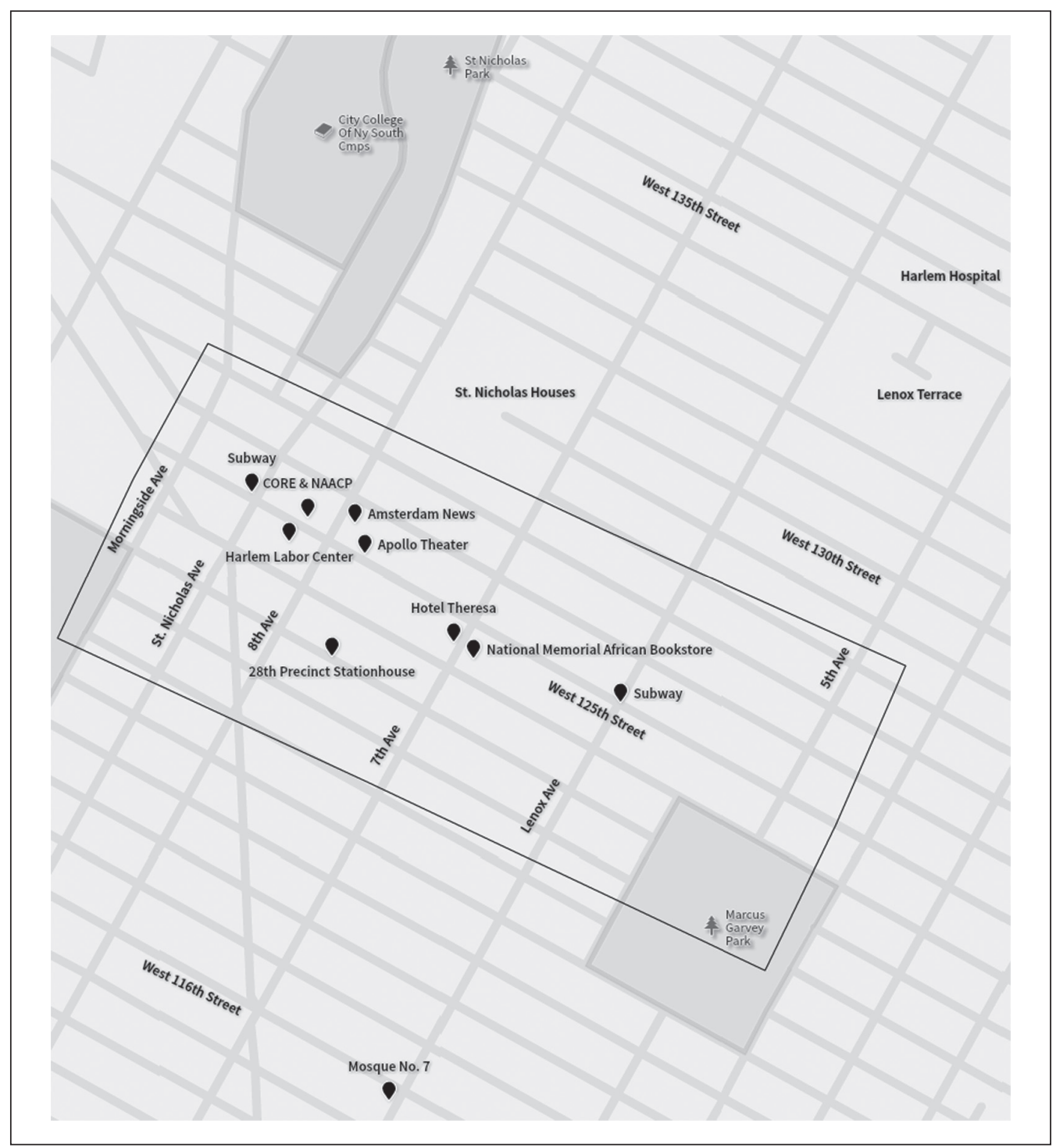

Figure I. The central business district of Central Harlem. This is where most political gatherings and rallies occurred. The corners of West I25th Street and Seventh Avenue were the most popular locations. However, as these corners filled, various groups and speakers moved north or south on Seventh Avenue or east and west on West 125th Street. Nevertheless, West 125th Street in its entirety was extremely popular with activists setting tables or roaming the sidewalks asking pedestrians to sign petitions, join their organizations, register to vote, take newsletters, or buy newspapers. This is the area where the Harlem Riot of 1964 also began.

Bedford-Stuyvesant in Brooklyn where a peaceful demonstration also escalated into a violent confrontation with the police. ${ }^{2}$

While it is difficult to determine the exact causes of this or any other major uprising of the 1960s, the acrimonious relationship between the police and the community contributed far more than just the spark. In his study of the northern civil rights movement, Thomas J. Sugrue contends that of "all the underlying causes of rioting, nothing mattered more than police-community 
conflict." ${ }^{\text {"3 }}$ Robert M. Fogelson argues that "it is impossible to conceive of the riots erupting with the same frequency or assuming the same form were it not for the ghetto's intense resentment of the police." 4 Harlan Hahn and Joe R. Feagin claim that "not only were policemen and black ghetto residents principal antagonists in civil disorders, but the animosities between them also were a significant impetus for violence." James W. Button states that "the most frequently cited grievance of blacks in riot cities was 'police practices' vis-à-vis Negroes, and no other single factor precipitated so much violence so often as did some form of incident involving blacks and the police." ${ }^{\prime 6}$ Survey after survey during the period revealed that one of the overriding concerns of urban blacks was police misconduct and that this issue functioned as one of the primary causes of riots. ${ }^{7}$ Despite these assessments, many historians of the black freedom movement have taken the antagonistic police-community relationship for granted and focused on other issues. This is partly because the repressive behavior of the police is seen as a reflection of the larger power structure and partly because civil rights-influenced legislation focused on schools, housing, public accommodations, voting rights, and employment.

In recent years, there has been a reexamination of the black freedom movement, and this includes growing attention paid to the criminal justice system in general and the police in particular. ${ }^{8}$ When it comes to New York City, Martha Biondi argues that beginning in the 1940s, "activists developed a comprehensive agenda for criminal justice reform, including protection from unreasonable search and seizure, a halt to coerced confessions, the creation of an independent civilian complaint-review board, a law to end police immunity from criminal prosecution, greater accountability and disciplinary procedures within the department, more Black police officers, an end to media stereotyping of Black men as criminals, a halt to the criminalization of poor, minority neighborhoods, and better, fairer policing of Black neighborhoods." Clarence Taylor demonstrates how in the immediate postwar period, New York City civil rights organizations intensified their mobilizations against police brutality, with the Communist Party playing an important role. ${ }^{10}$ Marilynn Johnson contends that policing acquired a strong discriminatory racial dimension in early twentieth-century New York and that eventual civil rights challenges to this practice led to unremitting conflict. ${ }^{11}$ This article adds to these perspectives by providing a history of the NYPD in the twenty years after World War II with an emphasis on the organization's relations with minority populations. During this period, crime rates increased (Figure 2) while corruption remained a common attribute of police behavior. City administrations, understanding that citizens demanded effective policing and that rising crime undermined New York's desirability, attempted to make the NYPD a corruption-free, disciplined, efficient, and responsive organization. These efforts were at odds with the desire of police rank and file to minimize management interference, work less, receive higher pay, supplement that pay with "gratuities," participate in collective bargaining, and neutralize challenges by black freedom groups. While patrolmen resisted the reforms that their police commissioners attempted to institute, relationships between the NYPD and minority communities became increasingly acrimonious. Black civic organizations that were fighting for a more equitable distribution of municipal recourses became the most ardent critics of the NYPD, which they branded as a failed institution.

This deterioration in policing poses a number of questions about the urban crisis. While suburbanization, deindustrialization, and fiscal stress help explain the decline of New York in the postwar period, would it be possible for the city to remain residentially desirable without adequate policing? While it is difficult to determine the causes of rising crime, and many historians and social scientists view changes in crime as structural, would it be possible to argue that an inefficient and corrupt police force did not contribute to the problem? Finally, how could blacks and Latinos who were moving to the city in great numbers during this period be incorporated into urban life, if the policing of their neighborhoods was impulsive and inadequate? 


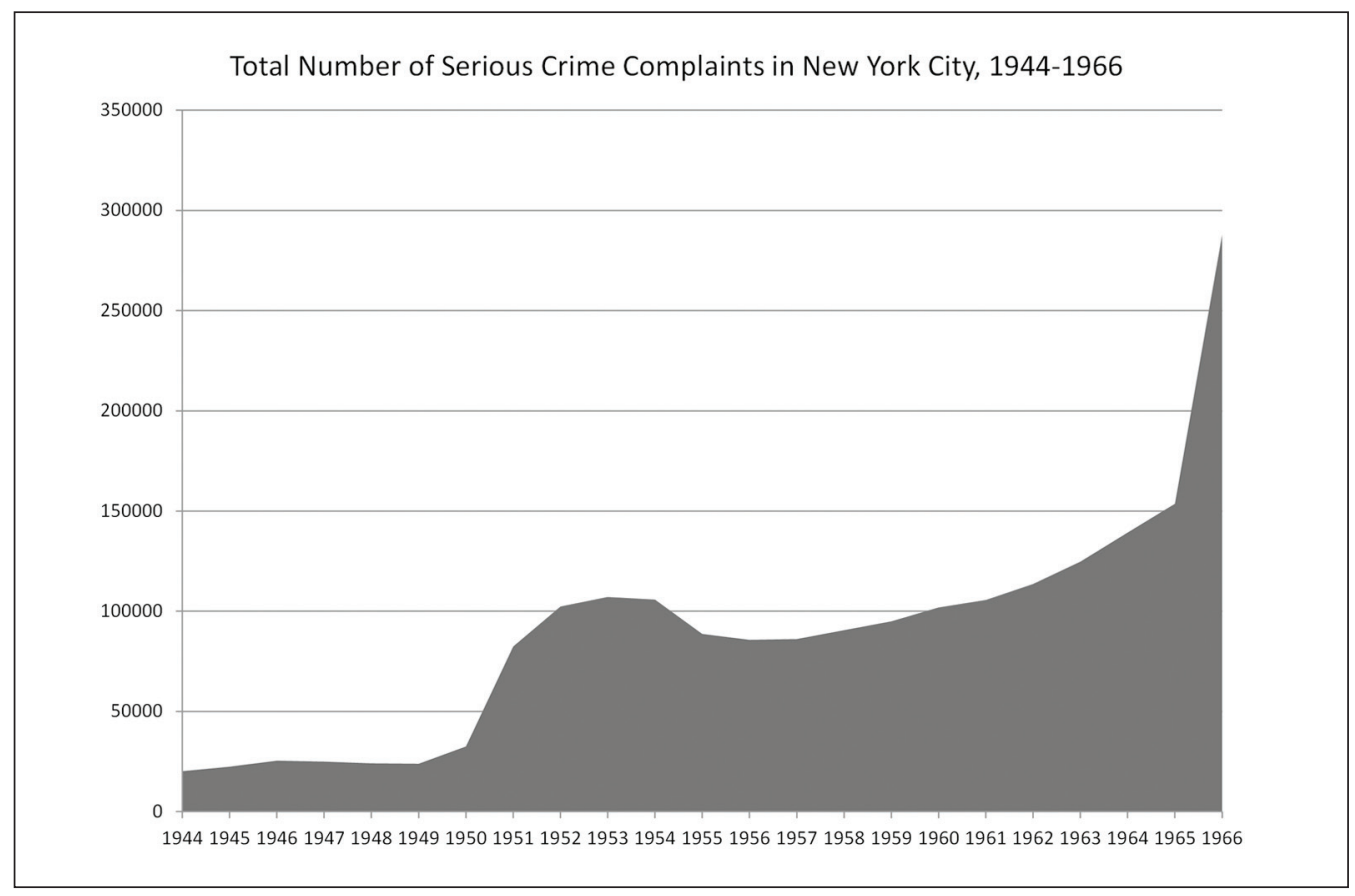

Figure 2. Total number of serious crime complaints in New York City by year.

Note: This category is the sum of murders, rapes, robberies, assaults, burglaries, larcenies, arson, and thefts. Given problems with crime reporting by the NYPD, the accuracy of these figures is compromised. For example, the rapid increases in 1950, 195I, and 1952 are due to severe underreporting in the years before. The 1966 spike is also due to underreporting in the years before. The city administration conducted statistical approximations and claimed that the gathering of crime statistics became deficient in the early 1960s. While the quality of policing including the reporting of crimes deteriorated under Murphy whose tenure as police commissioner began in $196 \mathrm{I}$, it is unclear when and to what extent the underreporting of crime actually began.

Source: NYPD Annual Reports, 1944-1967.

\section{The Making of the Most Problematic Municipal Agency, 1945- 1953}

On August 6, 1947, a rookie patrolman approached Lloyd Curtis Jones, a disabled African American veteran, who had been singing songs with friends near the Columbus Circle entrance of Central Park. The patrolman ordered Jones to move after checking his identification, but began to hit him with his nightstick because Jones did not move quickly enough. The patrolman ended up firing three shots into Jones's stomach, because Jones grabbed the nightstick away. The NYPD refused to discipline the patrolman, claiming that his response was not out of the ordinary. Jones was charged with disorderly conduct, but a felony court refused to convict him. ${ }^{12}$

The Jones shooting was one of numerous questionable police actions in the immediate postwar period, with New York City patrolmen brutalizing or killing black civilians. Some of these police actions included the following. On October, 29, 1945, patrolmen emptied their guns on a black driver on Eighth Avenue and West 144th Street in Harlem. The man, who had been pursued by a police patrol car, was coming out of his Buick sedan with his hands raised in surrender. After the patrolmen shot him, a crowd gathered in protest; police reinforcements arrived and chased the protesters away, clubbing a few of them. On June 7, 1948, Stephen Moses and his wife Tressie Mae Moses were accosted and beaten by two plainclothes police officers across the street from their home in Brooklyn while they were carrying bundles of clothes. On May 8, 1950, Thurmond 
Towns, a garment worker from the Bronx, was shot and killed in St. Nicholas Park in Harlem. The patrolmen claimed that he ran away when they tried to question him about a purse snatched from a woman. This version of events was unlikely given that Towns, who was a union member, was regularly employed and had a large savings account. In all of these questionable incidents involving the police, the people victimized were African American men and women. World War II veterans represented a sizable portion of the victims. ${ }^{13}$

As violent acts committed by white patrolmen persisted, African American civic organizations complained to the city government while resentment toward the police in the streets of black neighborhoods was mounting. In 1946, Police Commissioner Arthur Wallander (19451949) denounced charges of police brutality and argued that a petition sent to the mayor was baseless. The following year, a number of prominent Harlem citizens met with Wallander and convinced him to appoint the Citizens Committee to End Police Brutality, which would investigate a number of controversial cases. To be sure, the committee could only make recommendations, but its official sanction represented an improvement given that police officials seldom recognized that police brutality existed. However, the committee remained inactive and the New York Branch of the National Association for the Advancement of Colored People (NAACP) called for the resignation of the national organization's representative, so that it could take legal action against the NYPD by itself. Then in May of 1948, popular disturbances occurred at West 116th Street and Lenox Avenue in Harlem after rumors that a white patrolman had struck and killed a black woman. The city government sought strategies to better inform Harlem residents on police matters and the committee promised hearings on police brutality. The New York NAACP demanded that these hearings were public, something that the mayor and the committee rejected. At that point, the various organizations of the NAACP in the city held a rally outside City Hall. However, a gambling scandal caused the resignation of the police commissioner in 1949. The mayor also resigned in 1950. With police brutality incidents becoming commonplace in many parts of the country, in 1951, the Civil Rights Congress submitted a 240-page petition/ report entitled We Charge Genocide to the United Nations. The report, which described hundreds of cases in which patrolmen had assaulted or killed African Americans in the United States, argued that police bullets were replacing the lynch rope. ${ }^{14}$

With complaints continuing to come from civil rights organizations, in 1952, the U.S. Department of Justice sent FBI officers to New York to investigate allegations of police brutality. Police Commissioner George P. Monaghan (1950-1954) contacted the U.S. Justice Department and argued that this investigation threatened to completely destroy whatever morale was left within the ranks of the NYPD. In July of 1952, Monaghan made a deal with the head of the Criminal Division of the U.S. Department of Justice James McInerney and U.S. Attorney Myles Lane under which he promised to conduct his own thorough investigation on police brutality, if the FBI suspended its own for a while. However, a few weeks later, NYPD patrolmen, in Hell's Kitchen, brutally beat Jacob Jackson and Samuel Crawford while handcuffed. Monaghan refused to allow Assistant U.S. Attorney Daniel Greenberg to have FBI agents interview the NYPD patrolmen in the case and instead sent him a copy of an internal investigation; Greenberg found that report to be worthless. After Monaghan continued to stall, U.S. Attorney General James McGranery invalidated the agreement of Monaghan and McInerney. In February of 1953, Monaghan traveled to Washington, D.C., to meet with the Justice Department appointees of newly inaugurated president Dwight Eisenhower; however, these officials refused Monaghan's outreach and leaked the previous agreement to the press. Civil rights groups became especially furious when they discovered the existence of this agreement while white ethnic organizations congratulated and praised Monaghan. ${ }^{15}$

Recognizing that Monaghan's efforts to undercut federal oversight had the possibility of undermining civil rights enforcement in the rest of the nation, U.S. Congressman Adam Clayton Powell convinced his colleagues on the House Judiciary Committee to conduct an investigation 
into the agreement and its implications. NYPD officials denied the existence of any secret agreements while Monaghan called people demanding his resignation "un-American." Mayor Vincent R. Impellitteri (1950-1953) continued to strongly support his police commissioner while the Patrolmen's Benevolent Association (PBA) responded by authoring a forty-two-page statement in which it argued that civil rights groups were used by communists who wanted to weaken the NYPD. One of the PBA's main contentions was that communists believed that the police "must be annihilated or at least immobilized before any country can be successfully communized." 16 In the end, the House Judiciary Committee did not act on police brutality and issued a report that downplayed the issue. ${ }^{17}$

Despite all this, the NYPD created a Civilian Complaint Review Board (CCRB), staffed by three police officials who reported directly to the police commissioner, in order to investigate complaints by civilians against the police. The move was a reaction to the controversy created by Monaghan's FBI agreement and an attempt by the Impellitteri administration to assuage the concerns of community organizations. While the CCRB proved to be ineffective in changing the NYPD's record in police brutality cases, its existence formalized the complaint process. ${ }^{18}$

In the immediate postwar period, the NYPD became the most problematic city agency in New York City, with police brutality being only one of numerous problems. The years between 1949 and 1953 were especially difficult for the NYPD, with scandals, irregularities, investigations, and unfavorable reports surfacing every year. These problems compromised the ability of patrolmen to deal with many emerging crime problems in the years that followed.

Things began to fall apart for the NYPD in 1949 when FBI administrators announced that they could no longer publish New York City crime figures in the Uniform Crime Reports Bulletin because they were too untrustworthy. Many officials in other cities had been complaining that the NYPD was not complying with the FBI data guidelines and that crime rates submitted about New York City were too low to be true. Indeed, many smaller cities that had modernized their gathering of crime statistics were regularly reporting higher crime rates in all categories. In 1948, the NYPD reported 2,728 burglaries as opposed to 11,743 in Chicago, 4,793 in Philadelphia, 10,363 in Los Angeles, and 8,977 in Detroit. The NYPD also reported 7,713 larcenies versus 16,785 in Chicago, 4,000 in Philadelphia, 27,500 in Los Angeles, and 22,100 in Detroit. These numbers did not correspond to records of insurance companies, which showed that they paid on many more larceny losses than the NYPD reported. New York police officials tried to spin the problem as a disagreement between the NYPD and the FBI over crime reporting procedures, but this did not work. The discrepancy between reported and actual crime statistics explained the high number of complaints sent to the mayor about rising crime and police corruption. Although the majority of complaints came from people who concealed their names because they feared police retaliation, some of these complaints came from civic organizations. The result was always the same; police investigators usually reported that they were unable to confirm the alleged criminal conditions after surveying the area or that the problem used to exist but had since been corrected. Most of these NYPD responses were too dismissive of the complainants to be accurate. ${ }^{19}$

Under pressure, in 1950, the NYPD improved the way that crime complaints were documented and the results were staggering. The number of larcenies rose by 700 percent, robberies by 400 percent, assaults with gun and knife by 200 percent, and burglaries by 1,300 percent. The District Attorney of the County of New York, Frank Hogan discovered that crime statistics prior to 1950 were meaningless: usually the information provided by a complainant was thrown away. Patrolmen had even invented terms for this practice, joking that they had referred the crime complaint to the "detective can" or that the complaint had been "canned." In 1950, NYPD officials instructed police rank and file to record all complaints and that canning would no longer be tolerated. In fact, an April 1951 inspection revealed that despite the increase in crime statistics, police personnel were still dismissing many complaints, and further steps were taken to change the practice. ${ }^{20}$ 
Another problem for the NYPD was illegal gambling operated by organized crime syndicates. Despite Mayor William O'Dwyer's (1946-1950) orders to tackle illegal gambling, bookmakers increased their activities and paid police to look the other way or even assist their operations. Complaints about illegal gambling and the cooperation of the NYPD inundated elected officials and law enforcement organizations. In July of 1947, an anonymous writer sent a letter to Governor Thomas E. Dewey that provided accounts of police protection for bookmaking in specific stores, houses, and street corners of Astoria, Queens. The writer, who did not disapprove of the practice of gambling but the way that its illegality made for a corrupt police force, argued that a pending probe by a Queens Grand Jury had only made the police more cautious. A month later, O'Dwyer appeared to be agreeing with this letter writer and argued that existing gambling laws had a tendency to breed corruption in the NYPD, and that although he was skeptical about them, he would still try to keep his administration free of corruption. This statement of the mayor over gambling confused many observers. In January of 1950, the mayor's ambivalence to illegal gambling grew even more. O'Dwyer sent a letter to state legislative leaders likening the illegality of gambling to the prohibition of alcohol and made a case for the legalization and regulation of sports gambling by the state. He also claimed that the enforcement of antigambling legislation required too many resources that would be preferable to allocate elsewhere. Almost immediately, DA Hogan criticized O'Dwyer's suggestion of legalizing gambling. Governor Dewey stated that the NYPD was capable of enforcing antigambling laws if the city administration wanted, and that he would hold the mayor and his police commissioner responsible if they did not. Meanwhile, a Brooklyn Grand Jury headed by Brooklyn DA Miles F. McDonald began to unearth evidence of police cooperation with the gambling operations of organized crime. O'Dwyer verbally attacked McDonald, called the Grand Jury inquiry a "witch hunt," and took the side of the NYPD. After these attacks, the Brooklyn Grand Jury investigated the conduct of McDonald himself but exonerated him and continued its investigations. As the Brooklyn Grand Jury was stumbling into more evidence of police graft, O’Dwyer resigned. President Harry Truman appointed O'Dwyer U.S. Ambassador to Mexico. Although O'Dwyer relinquished his ambassadorship in 1952, he stayed in Mexico City until 1960. Police Commissioner Thomas P. O'Brien (1949-1950), who replaced Wallander at the beginning of 1949 , also resigned during the investigation after trying to blame his departmental troubles on a communist conspiracy. ${ }^{21}$

The reverberations of the scandal lasted until 1953, with arrests, trials, and departmental proceedings taking place. Gambling kingpin Harry Gross and dozens of police who protected his organization were indicted. The city administration dismissed almost fifty patrolmen for corruption. Many high-ranking commanders were also fired. Another 150 police involved in the affair resigned or retired. Efforts to distance the NYPD from the scandal consumed the entire term of Mayor Impellitteri. ${ }^{22}$

In an effort to rebuild the NYPD, Impellitteri hired Bruce Smith of the Institute of Public Administration to survey the department. Smith, an international expert on criminal justice, had helped to reorganize about fifty police departments in the United States. Released in October of 1952, after a fifteen-month investigation, Smith's report was highly critical of the NYPD. The investigation found that the clearance rate for auto thefts, robberies, burglaries, and other larcenies was 50 percent below the national average. More than eleven hundred patrolmen were involved in clerical and mechanical tasks, which could be performed more efficiently by trained civilians for significantly lower salaries. An additional two thousand patrolmen performed unnecessary or unproductive duties. Police personnel routinely abused sick leave. Patrolmen in charge of switchboards carried conversations, prolonging the average response time for emergencies to four or five minutes. The cases of 80 percent of patrolmen charged with misconduct were handled with extreme leniency; these cases included more than two hundred assaults on civilians, many of which were committed by intoxicated patrolmen. The study also argued that in many cases, the NYPD recruited rejects from the private sector and people who could not adjust 
to society. Despite these findings, Smith's conclusions were not too harsh; twenty years before, he had recommended that the City of Chicago fire its entire police force. ${ }^{23}$

In the following months, instead of reforming the NYPD, the Impellitteri administration grappled with the findings of the study and eventually shelved it. Police organizations including the PBA scored the study as biased. Monaghan took issue with many of the conclusions of the study, strongly defended patrolmen, and argued that the characterizations of personnel in the report as misfits and industrial rejects were unfair and inaccurate. Deputy Mayor Charles Horowitz concluded that the report was "junk." After hearings on the matter, the report was dismissed without action. ${ }^{24}$ While there was no police reform under Impellitteri, his defeat in the mayoral election of 1953 by Robert F. Wagner (1954-1965) renewed hopes for improvements.

\section{The Era of Failed Reform, 1954-196 I}

When Wagner took office as mayor in 1954, he felt that the NYPD required substantial reforms, if it was to adequately serve the city. Many observers had repeatedly charged that the police force was corrupt, racist, and inefficient. In order to correct this, Wagner appointed independent, strong-minded, and reformist police commissioners. Indeed, his first two commissioners turned out to be so independent that they frequently clashed with the mayor himself. However, they experienced the greatest resistance from the PBA, which functioned as the patrolmen's labor union; the association took advantage of a growing conservative political climate and changes in city policy in order to consolidate its power. By the early 1960s, despite having lost numerous battles, the PBA came out intact and more powerful.

Wagner's first police commissioner, Francis W. H. Adams, took office with a determination to reorganize the NYPD and improve its efficiency. He asked Chief Inspector Stephen P. Kennedy to enforce discipline on the force and to establish mechanisms that would prevent the cooperation of police and criminals. For a few weeks, the PBA privately criticized Kennedy's initiatives. Then, on February 9, 1954, three hundred delegates of the PBA met and issued a resolution that bitterly attacked Adams. They charged that with Kennedy's assistance, Adams had established a "shoo-fly" system. The term "shoo-fly," which originally referred to criminals warning other criminals of police movements, was eventually used to mean a police officer who spied on colleagues and reported them to superiors. The PBA alleged that under Adams, violations reported as part of the "shoo-fly" system included patrolmen wearing the wrong color socks, drinking coffee, or chatting while on duty. The PBA also attacked Adams for abolishing the Police Glee Club and Band. The PBA's leadership requested that Wagner overrule his commissioner in these matters. Immediately, the Citizens Union came to the defense of Adams and likened his efforts to build up discipline and efficiency in the NYPD to "the tradition of our best police commissioners such as Theodore Roosevelt, Arthur Woods, and George McLaughlin." The Citizens Union asked "whether the commissioner or the police brass is to run the department." 25 In the decades that followed, there was no satisfactory answer to this question. A few days later, Wagner publicly announced that he supported his police commissioner 100 percent and that he was working to elevate that number to 1,000 percent. Adams publicly asserted that he opposed efforts by labor unions to organize the NYPD. Bruce Smith entered the debate, stating that police discipline in New York approximated the nation's worst. ${ }^{26}$

Having prevailed, Adams continued to reorganize the NYPD. In the spring of 1954, Adams restructured the Midtown Squad, which was an independent unit that policed Midtown Manhattan's shopping area. He assigned the members of the squad into precincts so that their patrols could be integrated with those of other local patrolmen. Adams also reduced the number of emergency service squads, because records showed that some of them had responded to an extremely low number of heavy duty emergencies and discontinued detective districts so that borough detective commanders could direct investigations more efficiently. Furthermore, Adams 
merged the Headquarters Division with the Motor Transport and Maintenance Division and created a Bureau of Technical Services, transferred seven hundred patrolmen to active duty, devised a plan to civilianize crossing guards, and redesigned disciplinary proceedings. In the remainder of 1954, Adams shortened the top command of the NYPD, tightened regulations concerning personnel favoritism within the department, expanded the Narcotics Squad from one hundred thirty to two hundred detectives, directed the department's division of licenses to enforce the compliance of groups organizing public dances, urged the business community to stop giving holiday gratuities to police personnel, and strengthened the department's handling of juvenile delinquency by scrapping the old system and establishing Precinct Youth Councils. ${ }^{27}$

Crime rates continued to rise in 1954, though there were reasons for optimism. While serious crime increased by 8.9 percent in the first six months of 1954, it decreased by 3.8 percent in the second half of the year. The NYPD appeared to be operating more efficiently, since the overall clearance rate of all major felony crimes reached 36.5 percent in comparison to 23.5 percent the year before. Adams argued that despite the much needed reforms, the NYPD required thousands of additional patrolmen to meet the demands of the growing population of the city; otherwise New York would become a "community of violence and crime." 28 He illustrated his point about manpower by showing how in 1932, New York City had 18,315 patrolmen, only 500 fewer than in 1954 . However, the population of the city had increased by more than one million, street mileage by 1,000 miles, dwelling units by 350,000 , and motor vehicles by 600,000 . In addition, patrolmen worked between 6 and 8.5 fewer hours each week and received at least one additional week of vacation each year. Wagner was convinced that such an increase in personnel was needed and authorized the appointment of about 1,500 new patrolmen by February of 1955 so that he could instill a climate of "law and order." This appeared to be working because in the first half of 1955 , rates of serious crime declined by 13 percent. The clearance of serious crimes rose to 46.9 percent. $^{29}$

In the summer of 1955, Adams resigned in order to rejoin his law firm and Wagner appointed Stephen P. Kennedy as his police commissioner. Known as a hard worker, strict disciplinarian, and incorruptible, Kennedy was behind many of the successful projects and reorganizations that the NYPD had undergone during his predecessor's time. Wagner appointed Kennedy because he knew that he would demand that the NYPD operate at peak performance. Indeed, Kennedy created a system under which he rewarded productive detectives and officers and demoted or transferred non-productive ones. In his first policy speech to the department, Kennedy warned ranking officers not to resist his reforms and argued that laggard personnel had no place in the NYPD. The PBA considered Kennedy's appointment to be an affront. Kennedy had been accused of actually instituting the "shoo-fly" system under Adams and was seen as the architect of many disciplinary procedures established in the 1954-1955 period. More than this, many patrolmen thought that Kennedy was pretentious because he had shed his working-class Brooklyn accent and culture. ${ }^{30}$

In the months that followed his appointment as commissioner, Kennedy began to shake up the NYPD. Almost immediately, he transferred twenty-three men from the Coney Island force because they were possibly implicated or knew about sexual activities with two fifteen-year-old girls. Days later, he bypassed the morals squad of South Brooklyn and had a special unit raid gambling establishments. Kennedy also appointed a squad to investigate police involvement in questionable morals cases in Brooklyn. A version of this squad was maintained throughout his tenure; he used it to monitor, investigate, and arrest corrupt police personnel. In his efficiency campaigns, which sometimes included him personally checking on patrolmen and their superiors to see if they were at their posts, Kennedy demoted hundreds of detectives, disciplined tens of them, and transferred many commanders. Hundreds of sergeants and tens of lieutenants were also rotated. The Sergeants Benevolent Association took exception to newspaper reports that applauded these transfers. The reports claimed that men who remained in the same precinct for 
too long became stagnant. Sergeants felt that they were unfairly targeted because otherwise patrolmen and captains would also be rotated. Kennedy transferred so many sergeants because he had information that they had become coordinators of bribe schemes. Kennedy also required newer and tougher detective tests and eliminated an old practice of allowing a patrolman to attend detective school because of an act of bravery. In July of 1956, Kennedy asked all detectives to file reports on their activities over the past thirty months. He placed those who provided unsatisfactory answers on uniformed patrol duty. ${ }^{31}$

Kennedy was credited with many initiatives that managed to reduce serious crime in lowincome neighborhoods. In 1954, in his role as chief inspector, Kennedy designed Operation 25 in the 25th Precinct of Manhattan, which encompassed the area between West 110th and 147th Streets west of Fifth Avenue. Most of this area was in Harlem. Although 186 patrolmen worked in the precinct, only 25 percent of them were available for patrol duty because the rest were usually assigned for special and emergency services. Kennedy assigned the entire graduating class of 250 recruits to foot patrol in the 25th Precinct during the last quarter of 1954 . Kennedy also strengthened the detective, traffic, emergency, and youth services divisions of the precinct. Two and a half months later, robberies had declined by 71 percent, burglaries by 54 percent, grand larcenies by 58.3 percent, and auto-thefts by 69.4 percent. In general, the crime rates were lower while arrests and clearance rates were higher. Once Kennedy became police commissioner, versions of Operation 25 were successfully tried in various high crime areas of the city. He deployed additional patrolmen in parts of the southern Bronx, northern Manhattan, and central Brooklyn. When in the beginning of 1958, serious crime increased by more than 8 percent in Brooklyn, Kennedy ordered all 660 rookie patrolmen on foot patrol duty in high-crime parts of the borough. The problem with this strategy was that it was highly irregular: the NYPD lacked the resources to implement these programs on a more comprehensive basis. Kennedy expected Wagner to appropriate funds for 5,000-7,000 additional patrolmen, which did not happen. Although crime rates declined by more than 16 percent in 1955, they began to slowly inch upward in subsequent years (Figure 2). To his dismay, in the long run, Kennedy had to reduce the number of beat patrolmen because of personnel shortages. ${ }^{32}$

Despite various successes, Kennedy's tenure coincided with numerous incidents in Harlem between patrolmen and civilians that could have escalated into serious mass disturbances. On one of those occasions on Friday, April 30, 1957, Hinton Johnson, a member of the Muhammad Temple of Islam who had taken the name of Hinton X, had his skull cracked by patrolman Mike Dolan at West 123rd Street and Lenox Avenue. It all started when an intoxicated Reese Poe was seen by police beating a woman. Patrolman Ralph Plaisance tried to arrest Poe who allegedly resisted arrest and bit him. Another patrolman joined the scuffle and was allegedly also bitten by Poe who was powerfully built and difficult to subdue. As the patrolmen were beating Poe with their nightsticks, Hinton in the company of Lypsie Tall and Frankie Lee Pots approached the scene of the incident. The patrolmen told the three men to move. According to the police, the civilians instead remarked, "You're not in Alabama - this is New York." 33 Patrolman Dolan who had just arrived to the scene attempted to place Hinton under arrest for failing to move. Dolan claimed that he had to hit Hinton with his nightstick because he resisted arrest, though his account was later discredited. Everyone else at the scene was also arrested and brought to the 28th Precinct station house. A woman who witnessed the episode went to the Muslim restaurant on Lenox Avenue and informed people there. Minister Malcolm X went to the police station and asked to see Hinton. The police first claimed that they did not have Hinton in the station. Then they said that Hinton was in jail but that Malcolm could not see him. Malcolm replied that the hundreds of Black Muslims who had surrounded the station house would not leave unless he was allowed to see Hinton. As the crowd outside the station swelled into thousands, the police called a number of prominent citizens to go to the stationhouse and calm the situation. James Hicks, editor of the New York Amsterdam News, told the police that only Malcolm X could peacefully disperse the 
crowd. The police arranged a meeting with Malcolm in Hicks's office. However, when Malcolm got there, Deputy Police Commissioner Walter Arm told him that he wanted the demonstrators dispersed and that he was telling, not begging. Malcolm began to walk out when Hicks followed him and asked him to reconsider. Malcolm returned and asked to see Hinton and in case he was injured to have an ambulance take him to a hospital. Police officials accepted. Hinton told Malcolm that when he got to the station he was suffering from the blows of the nightstick and fell down on his knees. Once in that position he started to pray. At that point, the lieutenant in charge approached Hinton and hit him with a nightstick in the mouth and the shins. Since Hinton was bleeding badly Malcolm requested an ambulance. As more than two thousand Black Muslims, nationalists, and Harlem residents gathered outside Harlem hospital, the police prepared for a riot. To everyone's surprise, Hinton was released from the hospital and taken back to the police station. Malcolm went with his attorney Charles J. Beavers to the station and arranged bail for Pots and Tall. After seeing Hinton, Beavers requested that he be sent to a hospital; the police refused, claiming that he had just been to one. Beavers requested a pillow for Hinton to rest his injured head, but the police refused. They finally permitted to fold Hinton's coat and use it as a pillow. Malcolm left the station house and gave a command to his followers who had congregated outside to leave. They did so immediately. The next day in court, the police pushed for Hinton's arraignment without his attorney's presence who was in the same building working in another case. The judge set bail at $\$ 2,300$, which the Black Muslims paid. They waited outside where the police were supposed to deliver Hinton. However, Hinton was set loose inside the building. Disoriented, he struggled to find his way out. After some time, he walked out stumbling and bleeding. The Black Muslims brought Hinton to Dr. Leona Turner, who ordered Hinton to a hospital immediately. He was taken to Sydenham Hospital in Harlem, where the doctors discovered a blood clot on the brain and internal bleeding. Hundreds of Black Muslims gathered outside the hospital. Malcolm told them to go home once he found out that some teenagers with zip guns had also gone there and that there could be trouble. As Hinton's condition worsened on Monday, May the 3rd, word spread in Harlem that if he died there would be a riot. Trying to defuse the situation, high-ranking police officials met secretly with Malcolm. They assured him that they were trying to correct any wrongs on the part of the police and that there was an investigation. Malcolm told them that Harry Buffins, who had been outside Harlem Hospital on Friday night, was ready to testify that a patrolman wearing shield number 2775 said, "I'd have shot the nigger but the other cops kept getting in my way." 34 Another officer pointed at Malcolm and said, "We should break that bastard's head because he is their leader." ${ }^{35}$ Because of Malcom's involvement, there were no popular disturbances. Hinton survived after a metal plate was inserted in his skull. Eventually, an all-white jury awarded him seventy-five thousand dollars, which was the largest award for police brutality in the city's history. ${ }^{36}$

On another occasion on Monday, July 13, 1959, Patrolman Norman Hammes and Lieutenant John Angrist dragged Carmela Caviglione from a Harlem restaurant by the hair to their patrol car while punching her and kicking her. The police sped away with Caviglione in their vehicle, but lost control and crashed into the center island dividing Seventh Avenue near West 117th Street. A crowd gathered around the police car and Charles Samuel, a postal clerk, asked the police who appeared to be beating Caviglione inside the car what they were doing. Patrolman Hammes got out of the car and grabbed Samuel while pulling his gun at the same time, despite Lieutenant Angrist's pleas that this was not necessary. Hammes's revolver accidentally went off and the bullet hit him in the hand and Angrist in the back. When Caviglione and Samuel were taken to the West 123rd Street police station, a crowd of more than five hundred angry protesters gathered outside. Middleweight boxing champion Sugar Ray Robinson was summoned to the police station to calm the crowd. He was able to get the demonstrators to disperse by telling them that the prisoners had not been beaten. However, Robinson told reporters later that it was obvious that Caviglione had been physically abused and that he lied to the crowd outside the station, so that 
he could prevent an explosive situation. In the aftermath of this event, Kennedy assigned eightyeight extra patrolmen to the embattled Harlem police station and hundreds more in other parts of the city where a majority of African Americans resided. Kennedy declared that "we are not going to stand for mob violence anywhere in the city." ${ }^{37}$ His statement did not take into consideration the possibility that the police involved in the Caviglione incident were at fault and that the community was genuinely concerned about police misconduct. ${ }^{38}$

In the days that followed, a number of responses revealed that there was no consensus in the black community regarding police behavior. General Counsel of the National Association for the Advancement of Colored People (NAACP) Thurgood Marshall expressed his support for Mayor Wagner and said that "they are crucifying that man [Kennedy]," even though he admitted that he might "be kicked for saying this." 39 Rev. William M. James of the Metropolitan Community Methodist Church on 126th Street and Madison Avenue told his congregation in a sermon that while police brutality had been a concern for the Harlem community, this was the wrong case for it. James was referring to information that Caviglione had a history of public violent episodes and that she was probably at fault. He went on to commend Kennedy for fighting graft and corruption in Harlem and requested that the police fought crime there even more. ${ }^{40}$ However, Aloncita Flood, the Vice President of the New York NAACP branch, in a WNYC radio broadcast claimed that recent mob violence in Harlem could be traced to a "pattern of discrimination and disinterest toward people of minority groups on the part of public agencies." ${ }^{41}$ Jawn A. Sandifer, Chairman of the New York NAACP Legal Redress Committee, charged that the "police, more than any other single factor, are responsible for the rising tensions."42 In a CBS interview, L. Joseph Overton, President of the New York branch of the NAACP called Harlem a "police state."43

These differing opinions reflected the paradox that defined the policing of minority areas such as Harlem during this period. On the one hand, patrolmen and their superiors did not pay much attention to crime; instead they looked the other way, received payoffs from organized crime, performed haphazardly, and tolerated conditions that would be unimaginable in affluent areas. On the other hand, patrolmen demanded deference and respect from African American civilians and routinely demeaned and brutalized individuals who appeared to be challenging their authority. On top of these problems, the incidence of crime in Harlem increased. In response, Harlem residents and their leaders appealed to the city administration for better police protection. They were heartened by determined police commissioners like Kennedy who went after corrupt police personnel and attempted to make the NYPD an efficient and responsible organization. Nonetheless, confrontations between African American civilians and white patrolmen continued and the split in the black community deepened, with some people requesting improved crime fighting and others demanding fairer treatment, even though the two were not mutually exclusive. The antagonism between African Americans and the NYPD intensified as black freedom organizations began to pay more attention to police behavior.

These incidents kept on happening because even Kennedy underestimated the extent to which corruption had immersed the NYPD and the degree to which racial antipathy interfered with police work. The case of Harlem illustrates this point. In 1955, Kennedy embarked on a reorganization of Harlem's police because the area had the reputation of being the numbers capital of New York City. Kennedy established a confidential police squad, which raided candy shops, cellars, stores, and other suspected numbers operators. Between 1956 and 1958, the squad managed to drive the numbers trade underground and probed many patrolmen who were allegedly collaborating with numbers operators. And yet, in 1959 it was revealed that the police in Harlem were still involved in most numbers operations. The intelligence division of the U.S. Internal Revenue Service investigated policy bankers in Harlem and East Harlem and ordered raids. Kennedy organized another secret squad, which photographed police engaged in corrupt activities and then arrested them. On March 3, 1959, Joseph Lucerda, a Harlem police sergeant who had recently retired, was arrested for drunk driving with almost twenty thousand dollars in cash and 
an additional sixteen thousand dollars of bank book listings in his car. The money had come from the sales of numbers. A Manhattan Grand Jury formed to investigate the police in Harlem concluded that the entire tenth division of the NYPD did not enforce gambling and vice laws and that its members probably took part in these operations. The Grand Jury also found a complete breakdown of numbers enforcement at the precinct level in Harlem and East Harlem, something that prompted Kennedy to further dismiss and reassign police personnel. Numbers operations in Harlem continued anyway. ${ }^{44}$

In 1960, U.S. Congressman Powell launched a campaign against the corrupt practices of the NYPD in Harlem by pointing out that numbers operations were thriving there. In response, the NYPD conducted raids and arrested a number of numbers operators. At a rally in the Abyssinian Church, Powell angrily denounced the NYPD for discriminatory practices when enforcing the law and declared that thirteen Italians were in charge of numbers games in Harlem because the police had arrested most black bankers. The NYPD had an official policy of ignoring Powell's comments, yet days later it raided Harlem again and arrested even more numbers operators. Powell continued his accusations that the NYPD was arresting minor black figures in the numbers system and was allowing major white bankers to continue their trade. He gave frequent speeches in the House floor in which he listed the names of operators, the addresses of betting places, and the amount of money paid to the police. Powell also provided the names of the small number of lawyers and bail bondsmen handling the cases of those arrested and claimed that the Mafia was paying them. The New York Post sent its own investigative team to Harlem and confirmed all of Powell's allegations in a series of articles. This proved quite embarrassing for Kennedy, the NYPD, and the city administration. In the early 1960s, city, state, and federal investigations revealed widespread corruption in Harlem that included the police and the courts. ${ }^{45}$

In the meantime, requests by Harlem leaders to appoint more African American patrolmen and ranking officers in black neighborhoods and to improve the quality of policing there were rejected by Kennedy. He declared that the NYPD did not make appointments on the basis of race, religion, or politics. Kennedy also did not accept requests to stop using Harlem as a place where new graduates of the police academy trained. He conceded that the NYPD used Harlem to assign "misfits" who were inappropriate for other parts of the city. However, Kennedy believed that this had changed and that the new recruits were well trained and capable. Harlem residents remained skeptical. ${ }^{46}$ In an essay published in 1960, James Baldwin expressed how a large proportion of the Harlem community felt about the police:

None of the Police Commissioner's men, even with the best will in the world, have any way of understanding the lives led by the people they swagger about in twos and threes controlling. Their very presence is an insult, and it would be, even if they spent their entire day feeding gumdrops to children. They represent the force of the white world, and that world's real intentions are, simply, for that world's criminal profit and ease, to keep the black man corralled up here, in his place. The badge, the gun in the holster, and the swinging club make vivid what will happen should his rebellion become overt. Rare, indeed, is the Harlem citizen, from the most circumspect church member to the most shiftless adolescent, who does not have a long tale to tell of police incompetence, injustice, or brutality. I myself have witnessed and endured it more than once. The businessmen and racketeers also have a story. And so do the prostitutes. ${ }^{47}$

While police behavior in African American neighborhoods had always been a concern, at the time that Baldwin wrote this essay, it was becoming an important organizing issue. In the years that followed, black freedom organizations began to confront the NYPD with regularity.

Besides problems with police misconduct in the field, Kennedy began to face serious challenges from the PBA when in 1958 Patrolman John J. Cassese became its president. Cassese defeated eleven-year PBA President John E. Carton arguing that the association needed a new, more activist leadership that would confront Kennedy and the Wagner administration. During his 
tenure as president, Cassese transformed the PBA into one of the greatest antagonists of city administrations. Cassese was elected as the leader of a more activist slate because patrolmen were upset over their declining status relative to management and along with that their declining incomes. Robert Fogelson has argued that before World War II police work was an important avenue of upward mobility for white ethnics: "For men who had little education and few skills . .. they received a decent salary that could be supplemented by regular payoffs, and if they put in their twenty or twenty-five years, could receive a modest pension." 48 In the postwar period, as police salaries failed to adjust to increasing costs of living and as payoffs became more risky, patrolmen grew increasingly dissatisfied. When compared to the salaries of teachers, plumbers, electricians, and draftsmen, patrolmen did not do as well. Meanwhile, commissioners such as Adams and Kennedy demanded outmost devotion, discipline, and peak performance from patrolmen, while dismissing all of their grievances and efforts to collectively organize. ${ }^{49}$

The first clash between Kennedy and Cassese concerned the issue of police unionization. Since becoming mayor, Wagner had been strengthening the right of municipal employees to bargain collectively. In 1954, Wagner signed an interim order allowing city employees to form associations that could negotiate terms and conditions of employment. In 1956, Wagner and the Board of Estimate granted municipal unions the right to dues checkoff. In 1957, Wagner permitted public employee labor leaders to carry out union business instead of performing their assigned agency tasks. In 1958, he issued Executive Order 49 (EO 49), which formalized the collective bargaining process and codified grievance procedures. All of these changes excluded the NYPD; the city administration decided to undertake further studies in order to determine whether EO 49 and other labor codes could apply to the police department. The PBA reacted to this exclusion by pressing for collective bargaining rights and threatening that patrolmen would join civilian labor unions. Weeks after Wagner's EO 49, Kennedy rejected a proposal by Labor Commissioner Harold A. Felix to hold hearings on whether municipal collective bargaining rules should also include the police arguing that unionization would undermine both the discipline and the impartiality of uniformed police. In response, Cassese demanded that the city government recognize the PBA as a bargaining agent for patrolmen, allow dues checkoff for the PBA, and designate a third party outside the NYPD that would arbitrate in disputes between the police commissioner and police rank and file. Wagner sided with Kennedy in rejecting all these demands, yet a year later he said that the PBA should be allowed to receive membership dues through a voluntary payroll checkoff. The Supreme Court of New York, with the support of Wagner, decided that despite stated exclusions, the Board of Estimate had granted the right to dues checkoff to all city employees and that the PBA was entitled to voluntary payroll deductions of its members. On the other hand, the PBA did not succeed in its court petition regarding grievances; the courts sided with the Wagner administration's decision to exclude the police from EO 49.50

While the conflict over unionization as well as other issues continued, there was a showdown between Kennedy and Cassese over moonlighting — patrolmen holding second jobs outside the department. In the latter part of 1960, Kennedy initiated disciplinary proceedings against patrolmen found to be holding second jobs in Brooklyn and the Bronx. This happened after a patrolman with 366 days of sick-leave in five years had earned more than forty thousand dollars for outside work. Cassese argued that the anti-moonlighting move was unfair and that the commissioner would have to go after fourteen thousand of the seventeen thousand patrolmen who held outside jobs because their police pay was inadequate. The PBA also organized fundraisers to help pay the fines of patrolmen. Kennedy threatened to dismiss any police personnel found soliciting or contributing funds to pay the fines of patrolmen penalized for moonlighting. In response, the patrolmen issued a ticket slowdown. In retaliation, Kennedy transferred Cassese from a desk job at headquarters to full-time traffic duty at an isolated location. Three days later, patrolmen issued 132 percent more tickets than on the corresponding day the year before. After an investigation, Kennedy characterized the ticket actions to be a strike and ousted hundreds of patrolmen from 
radio cars and placed them on foot beats. He also devised a new regulation that required all police personnel to sign individual forms affirming that they did not hold outside jobs. Weeks later, a police surgeon prohibited Cassese, who was on sick-leave because he had a broken toe, from attending a PBA meeting in a hotel in Manhattan; the PBA transferred the meeting to the basement of Cassese's building in Brooklyn and initiated proceedings to expel Kennedy from the association. The following day, Kennedy ripped up his PBA membership card in front of television cameras. The PBA expelled him. Meanwhile, patrolmen who were dismissed for holding second jobs could not convince the courts to declare Kennedy's moonlighting regulation invalid. The dismissed patrolmen cited a court decision that had sided with an employee of the Department of Welfare who was dismissed because he held a second job after hours. However, the courts argued that police work was different from welfare work because the police were expected to respond to emergencies and perform at peak capacity. In the end, Kennedy prevailed in this conflict with the PBA, though many patrolmen continued to secretly have outside jobs. ${ }^{51}$

Early in 1961, Kennedy resigned from his post. This occurred after Wagner decided to reappoint Kennedy to a new five-year term and Kennedy surprised him by saying that he would only accept if the mayor gave a hefty pay-raise to the police. Wagner refused though the pay-raise demand was a ploy. Kennedy and Wagner had been clashing more frequently during this period, but given Kennedy's popularity in the mass media, Wagner did not dare dismiss him. And there were more problems. Kennedy was coming under fire from many fronts. For example, he had offended Jewish groups by refusing to allow Jewish patrolmen take off work for the holidays. African American communities that had initially supported Kennedy had grown skeptical with his refusals to staff police precincts in minority communities with nonwhite patrolmen. They also had more and more grievances about the manner in which white patrolmen enforced the law. The Citizens Emergency Committee charged that fees levied on cabaret entertainers were transferred into the Police Pension Fund. They also alleged other corrupt practices and petitioned Governor Nelson Rockefeller to investigate the NYPD. Finally, the conflict between Kennedy and Cassese had made the police department lose focus. Wagner replaced Kennedy with Michael J. Murphy (1961-1965), who was thought to be less rigid. ${ }^{52}$

With Kennedy out of the way, Wagner and Murphy tried to appease the PBA. Weeks after taking over, Murphy established a police grievance procedure that Kennedy had opposed for many years. Patrolmen could now formally file grievances and appeal complaints to an authority outside the NYPD. The PBA also gained a 15 percent pay-raise for its members. In 1963, Wagner extended EO 49 to cover the NYPD. The problem with this accommodationist approach toward the rank and file of the NYPD was that Murphy scrapped many of Kennedy's policies, including his anticorruption drives. Graft made a resounding comeback in most departmental ranks. So did police indifference and misconduct. The gathering of crime statistics also suffered..$^{53}$

The failure to reform the NYPD during the Wagner years was disastrous, because the possibility existed and was wasted. The first two police commissioners appeared to be well organized, corruption free, and determined to modernize the force. They actually succeeded on many fronts, and this can be seen in the relative stability in crime rates during the second half of the 1950s. However, the preoccupation of Kennedy with labor issues (with the exception of moonlighting) was misdirected, and this contributed to an increased antagonism with the PBA. Wagner's inconsistency when it came to the conflict between Kennedy and the NYPD did not help the situation either and ended up strengthening the PBA. Moreover, Kennedy did not understand the extent to which corruption was consuming the NYPD. Gradually, many of his anticorruption campaigns became reactive, responding to discontent by the community or to investigations by the courts and the federal government. Finally Kennedy failed to fulfil many of the requests of black civic associations. While the demands for more black patrolmen in black neighborhoods may not have improved the quality of policing there, the almost complete disregard of most complaints made by black leaders indicates that Kennedy did not understand the worsening conditions in minority 
neighborhoods. Murphy's appointment in 1961 coincided with Wagner's growing disinterest in reforming city agencies and a desire to maintain a peace with public employee unions, even if this meant that the quality of municipal service delivery would suffer. The NYPD reverted to the unacceptable practices of 1946-1953, though this time it faced a more determined and contentious black freedom movement that was unwilling to accept police misconduct and inefficiency as a way of life.

\section{The Further Deterioration of Police-Community Relations}

While numerous organizations such local Democratic Party clubs, the Nation of Islam, the NAACP, and the YMCA were seeking the support and membership of black New Yorkers, in the early 1960s none of them was as successful as CORE. Unlike other organizations, CORE was not too restrictive, centralized, religious, or conservative.$^{54}$ Illustrative was a letter sent by Arthur A. Stone to Cynthia K. Homire of CORE in 1960. Stone wrote:

Your letter received today, with its pamphlet, was very welcome, I'll be darned if I ever heard of this group before, but it's exactly what I've been looking for, action; I joined the NAACP for 6 months, and not one action was taken, I was peeved, I've written Congressman Powell trying to interest him in a idea of mine to form a group that would fight all kinds of discrimination, against Negroes, Japanese, Mexicans, etc. and at last resort, I decided to form my own group, of friends I know. BUT, here you people were all setup, functioning and I never heard of you, and I wondered why, I think I know, CORE, sounds like a government agency, and tho I read of it, it never occurred to me it was a mass organization..$^{55}$

Stone expressed the feelings of many working-class African Americans who viewed the NAACP as a top-down reformist organization that had no interest in rallies, protest actions, and mass politics. This view of the NAACP may have been exaggerated, but many working-class blacks felt that the organization had lost touch with its base. Something similar had happened with the Urban League, which was usually even more conservative than the NAACP. In the early 1960s, CORE, with its decentralized structure and sponsorship of high-profile nonviolent direct actions in the South, appealed to many black New Yorkers. Because of the ease of establishing a CORE chapter, New York's CORE affiliates increased from three to nine. The Manhattan chapter moved its offices to Harlem, so that it would be in touch with the community. CORE chapters picketed stores that refused to hire African Americans, demonstrated against indifferent landlords, and organized rallies against racial discrimination in the North and the South. CORE activists also began to focus on the police, because police misbehavior in black neighborhoods was becoming too frequent and overt. In its December 1962 meeting in New Orleans, the National Action Committee of CORE articulated its concerns regarding police brutality and asked CORE chapters in both the North and the South to undertake direct action campaigns that addressed the police. Besides police brutality, the National Action Committee discussed several other forms of police malpractice, including illegal arrests, mass arrests, illegal searches, and improper detention. ${ }^{56}$

African Americans had three interrelated grievances when it came to the NYPD. The first concerned police inefficiency and corruption, the second police violence against demonstrators, and the third police brutality against individuals. CORE activists who were recruiting people in black neighborhoods discovered the extent to which police misconduct had become a significant organizing issue.

Police apathy and graft were citywide attributes, except that in low-income neighborhoods they were more profound and visible. Besides receiving small pay-offs and cut-rate products from all kinds of businesses, patrolmen and ranking officials were involved in numbers, drugs, 
gambling, and prostitution. Police participation in these operations was commonplace in minority neighborhoods such as Harlem and Bedford-Stuyvesant, and while under Adams and Kennedy there were various anticorruption initiatives and secret units, they focused on numbers and gambling because of their pervasiveness. Murphy dismantled these initiatives when he became police commissioner and denied that the NYPD was corrupt: "We have our faults . . . but I don't know of anyone who takes money from narcotics or prostitution. I don't know of any policeman who wouldn't despise a man who did that." ${ }^{57}$ Murphy did not deny police involvement in numbers and gambling, probably because two different grand juries were investigating the NYPD and numerous patrolmen and ranking officers had been arrested for such offenses. Whatever the case, illegal activities committed by the police became more overt and regular under Murphy, and this included the drug trade and prostitution. ${ }^{58}$

The issue of police violence against demonstrators grew in salience in the early 1960s after a series of vicious attacks against peaceful demonstrators in the South that were televised. In reaction, the membership of New York's CORE chapters increased and black freedom rallies and other protest actions in the city also multiplied, eliciting repressive police actions. When the NYPD used patrolmen on horses to attack demonstrators who were peacefully sitting on sidewalks, New York CORE chair Gladys Harrington said that "horses in New York are no different than police dogs in Birmingham." 59 In one of the biggest black political mobilizations in the history of New York, a campaign to integrate the construction workforce that was building the Downstate Medical Center in Brooklyn in 1963, demonstrators were frequently roughed up by the police. Police violence was exerted even against conservative church members who seldom took to the streets while hundreds of demonstrators were arrested by a police force that was viewed as overzealous. Demonstrators at the construction site of Harlem Hospital, Rochdale Village, City Hall, ABC studios, the police commissioner's office, the Triborough Bridge, the World's Fair, and other locations also encountered a police force determined to use any means necessary. As police actions intensified, organizations such as the New York Civil Liberties Union and the New York Metropolitan Council of the American Jewish Congress established panels of volunteer attorneys available to represent arrested civil rights demonstrators. ${ }^{60}$ The rhetoric also escalated. Tenant organizer Jesse Gray in a picket line in front of police headquarters declared that "we must prepare to set up a picket line in front of any police precinct in which an arrest is made regarding the rent strike. We must destroy the image that the New York Police are democratic and not on the side of the slumlords." ${ }^{61}$ Commissioner Murphy, who considered Reverend Herbert Callender, Minister Malcolm X, and Gray to be unreasonable agitators, replied, "to him and others of his ilk I say: We will not be intimidated. We reject your lies and so do the people of this city." 62

While police brutality against individuals in everyday situations had always been a problem for the black community, it worsened in the early 1960s, and the frequency of potentially explosive episodes increased. Louis E. Lomax wrote in 1962 that there were at least four black lawyers who worked on a percentage basis as specialists in police brutality cases, making more than twenty thousand dollars each year. He added that the City of New York paid more than one million dollars each year to settle police brutality cases, most of which involved black civilians. Lomax described the situation as follows:

The problem is aggravated in areas like Harlem where police brutality is an accepted fact of life. Without such cases to report, Negro newspapers would have considerable blank space. On the other hand, "transition areas," such as the one in which I live, are far from exempt. The white people are moving out but many of them are still here; the police are on the prowl for suspect Negroes, and some white family can be depended upon to sound the alarm that a Negro is lurking in the streets near their home. Any Negro who happens to be walking, or riding, for that matter, down that street is apt to be in for it. For this very reason, I always keep my press card in my hand when I am driving home late 
at night. I have been forced to pull my car to the curb by policemen four times in the past two years. Always my press card has ended the inquiry on the spot, but, in each instance, the police have told me they were looking for some Negro suspect. ${ }^{63}$

On April 17, 1963, in one incident that could have caused serious and prolonged disturbances, Frank Stafford, a licensed door-to-door salesman was arrested after he was savagely beaten on Lenox Avenue near West 128th Street. Stafford was taken to Harlem Hospital for emergency care and then to Bellevue Hospital for treatment of his damaged right eye, after a three- to four-hour beating inside the police station. Stafford stayed in the hospital for two weeks. He had an eye surgery, which failed. The doctors had to remove his right eye to prevent infection from moving to the left eye. The incident began when some schoolchildren grabbed some fruit that had fallen to the sidewalk from two overturned stands outside Joe's Fruit Stand on Lenox Avenue. Four patrolmen tried to catch the children, but the turmoil attracted older teenagers. The teenagers jeered the patrolmen, who called for reinforcements. More patrolmen arrived and began to attack people with their nightsticks around the area indiscriminately. Many of the patrolmen had also drawn their guns, aiming at people in windows and rooftops. Stafford was beaten after he questioned a patrolman beating a teenager. Fecundo Acion, a Puerto Rican seaman, was also beaten after he intervened. The police arrested a number of people including Stafford and Acion and continued the beatings inside the police station. Although there was no riot, the events on Lenox Avenue that afternoon could have caused one. The police charged Stafford with beating up a schoolteacher on West 127th and Lenox Avenue, causing trouble in the fruit stand between West 128th and West 129th on Lenox Avenue, and assaulting the police on 129th Street between Seventh and Lenox Avenues. However, witnesses saw Stafford selling women's stockings for most of this time; he was only involved in the end when the police attacked him. ${ }^{64}$

The day after Stafford's beating, Captain Carl Ravens of the 28th Precinct wrote to every church and community center in the precinct area requesting assistance to maintain order in the summer months. The letter stated that "the police have been plagued with near riots during the past two years while attempting to perform their duties," and that "the police have been hampered seriously while attempting to apprehend criminals." 65 This letter illustrated the extent to which the police believed to be acting properly in the midst of increased friction between its patrolmen and civilians. The community had its own interpretation, which was not as charitable to the police.

The incidents that almost resulted in riots usually occurred in the area around 125th Street, which was the main commercial thoroughfare of Harlem (Figure 1). ${ }^{66}$ Police actions around West 125th Street and Lenox, Seventh, and Eighth Avenues were dangerous because many people were proliferating and the indiscriminate clubbing of pedestrians did not always result in the desirable effect of having crowds disperse. The 28th police precinct located on West 123rd Street between Seventh and Eighth Avenues increasingly became an object of contention for many African Americans, with frequent protest actions outside of it. More than this, in the corner of Seventh Avenue and West 125th Street, black nationalists and other activists made speeches that gathered many passersby. CORE, located on West 125th Street between Eighth and St. Nicholas Avenues, held numerous gatherings in the area. The local chapter of the NAACP, located in the same building as CORE, held its own outdoor events as well and so did black churches from other Harlem locations. Hotel Theresa located on Seventh Avenue between West 124th Street and West 125th Street functioned as a meeting place where many black organizations regularly held high-profile rallies that attracted crowds into the thousands. Across the street, outside the National Memorial African Bookstore, activists held assemblies that drew thousands of people as well. On Lenox Avenue and West 116th Street, Mosque No. 7 of the Nation of Islam featured various religious and political events while the Black Muslims also held weekly gatherings in various locations around the business center of Harlem. By the early 1960s, the difficulties that the police 
experienced increased because central Harlem became an epicenter of oppositional political activity and ordinary people were no longer willing to defer to the police. ${ }^{67}$

The commercial center of Harlem is where the Harlem Riot of 1964 started. A CORE rally on Seventh Avenue and West 125th Street, protesting the killing of fifteen-year-old James Powell by Lieutenant Thomas Gilligan, ended with a march at the 28th precinct on West 123rd Street. After the crowd was pushed away from the exterior of the police station to Seventh Avenue, the crowd grew to more than a thousand; its dispersal by the police resulted in small groups that attacked stores. These groups were joined by others, and the disturbances spread to various blocks in and around the Harlem central business district. Although the insurrection also involved BedfordStuyvesant, there was no doubt at the time that the commercial center of Harlem was the epicenter of black activism and that police mishandlings threatened the peace of the area. Michael Flamm argues that the NYPD failed to adequately prepare for the aftermath of Powell's shooting and that it committed a number of strategic mistakes in its handling of the riot. ${ }^{68}$

In the aftermath of the riots, Mayor Wagner resorted to a number of symbolic actions. He increased the number of black patrolmen in Harlem and devised a new policy under which patrolmen would be responsible for informing the public in Harlem, East Harlem, and BedfordStuyvesant of the range of municipal services available to them. Captain Lloyd Sealy was the first black person to be appointed commander of the 28th precinct in Harlem. ${ }^{69}$ City council member Theodore Weiss resurrected his bid for a bill to create a Civilian Complaint Review Board staffed with nine civilians appointed by the mayor. ${ }^{70}$ Wagner stalled the bill, hoping that the urgency for it would pass. Police Commissioner Murphy opposed the bill and characterized charges of police brutality as "maliciously inspired" and a mechanism "aimed at destroying respect for law and order." use their guns during the disturbances of 1964, repeatedly dismissed claims of police brutality and attacked CORE and other civil rights organizations for being hypocritical and attempting to undermine the effectiveness of the police. In response, African Americans began to call him "Bull" Murphy after "Bull" Connor in Birmingham, Alabama, who had used fire hoses and attack dogs against civil rights demonstrators. Malcolm X contended that Murphy was "a dangerous man" because "his public statements give the policeman courage to incite violence." 72

Meanwhile, crime continued to increase and police responsiveness to decrease. In the spring of 1965, Wagner who was still considering a run for a fourth term as mayor announced "a war against crime," which he claimed to be his highest priority. ${ }^{73}$ In response, CORE declared open war on Wagner and his reelection campaign for a fourth term, because of his "complete apathy and disregard for the Negro and Puerto Rican communities and the major problems" of the city. ${ }^{74}$ Congressman Powell predicted that in the upcoming election "Mayor Wagner is a sure winner and the city is a sure loser." 75 Had he campaigned for a fourth term, Wagner would have been viciously attacked for having allowed crime to increase and the NYPD to deteriorate. However, he did not seek a fourth term. ${ }^{76}$

In 1965, John V. Lindsay, a liberal Republican congressman from the Upper East Side, ran for mayor of New York City. Lindsay blamed his predecessor for presiding over the deterioration of city agencies. While Lindsay was determined to remake the entire city government, he centered his 1965 mayoral campaign against the NYPD. As Jay Kriegel, Lindsay's chief of staff/special counsel, asserted, "the 1965 campaign in a real sense was run against the police force. Not that we thought they were racists, but that the department was old and tired, and badly in need of modernization. But institutionalized racism was an important issue - the problem of brutality and the lack of minorities in the force." 77 Lindsay promised that if elected, he would improve policecommunity relations, modernize the NYPD, and establish a civilian police review board. Though an underdog, Lindsay narrowly prevailed in the 1965 election.

From a civil rights point of view, Lindsay's victory functioned as a realization of many of the claims made by African American activists in the postwar period. Decades of police misconduct 
appeared to be coming to an end, and the establishment of a CCRB staffed by civilians satisfied one of the main goals of New York's black freedom movement. To be sure, the PBA managed to defeat Lindsay's CCRB in the polls in 1966 after being able to place the issue before the voters in the form of a referendum. Moreover, police efficiency declined even more while police corruption reached even higher levels. The Lindsay administration tried to modernize the NYPD; however, it underestimated the extent to which the organization had irreversibly broken down, the magnitude of police corruption, and the power of the agency to destabilize urban governance. In the end, things did not work out for Lindsay, but his administration's struggle for police reform appeased the black population of the city and deflated a tense and dangerous situation.

\section{Acknowledgments}

A portion of this article was presented at the Rutgers Center for Historical Analysis at Rutgers University, New Brunswick, U.S.A. in 2011. I would like to thank the participants of the seminar and the commentator Sheetal Chhabria for their useful suggestions. Another version of this article was presented at the Historians of the Twentieth Century United States/British American Nineteenth Century Historians Joint Conference, at the University of Reading, U.K. in 2014. The author would like to thank his fellow panelists Daniel Matlin and Andrew Fearnley, the chair of the panel Cheryl Hudson, and the audience for their beneficial comments. The author is also grateful to Emma Long from the University of East Anglia for her valuable input.

\section{Declaration of Conflicting Interests}

The author declared no potential conflicts of interest with respect to the research, authorship, and/or publication of this article.

\section{Funding}

The author received no financial support for the research, authorship, and/or publication of this article.

\section{Notes}

1. Fred C. Shapiro and James W. Sullivan, Race Riots: New York 1964 (New York: Thomas Y. Crowell, 1964), 47.

2. "The Gilligan Case: Report of the Congress of Racial Equality, September 2, 1964, The Papers of the Congress of Racial Equality (hereafter, CORE), 1941-1967, Series 5, Subseries 6, Butler Library, Columbia University; Shapiro and Sullivan, Race Riots: New York 1964, 1-13; Michael W. Flamm, "New York's Night of Birmingham Horror: The NYPD, the Harlem Riot of 1964, and the Politics of 'Law and Order,"' in Patterns of Provocation: Police and Public Disorder, ed. Richard Bessel and Clive Emsley (New York: Berghahn Books, 2000), 81-97.

3. Thomas J. Sugrue, Sweet Land of Liberty: The Forgotten Struggle for Civil Rights in the North (New York: Random House, 2008), 327.

4. Robert M. Fogelson, Violence as Protest: A Study of Riots and Ghettos (Garden City: Doubleday, 1971), 55.

5. Harlan Hahn and Joe R. Feagin, "Riot-Precipitating Police Practices: Attitudes in Urban Ghettos," Phylon 31 (2nd Qtr. 1970): 183.

6. James W. Button, Black Violence: Political Impact of the 1960s Riots (Princeton, NJ: Princeton University Press, 1978), 110-11.

7. Some of the surveys and reports include the following: United States Commission on Civil Rights Report, Book 5: Justice (Washington, DC: U.S. Government Printing Office, 1961); John F. Kraft, Inc., "The Attitudes of Negroes in Various Cities" in "Federal Role in Urban Affairs," Hearings before the Subcommittee on Government Operations, U.S. Senate, 89th Congress, 2nd session, August 31-September 1, 1966, Part 6; The President's Commission on Law Enforcement and Administration of Justice, Task Force Report: The Police (Washington, DC: U.S. Government Printing Office, 1967); The President's Commission on Law Enforcement and Administration of Justice, The Challenge 
of Crime in a Free Society (Washington, DC: U.S. Government Printing Office, 1967); U.S. Riot Commission, Report of The National Advisory Commission on Civil Disorders (New York: Bantam, 1968).

8. These works include Gail Williams O'Brien, The Color of the Law: Race, Violence, and Justice in the Post-World War II South (Chapel Hill: University of North Carolina Press, 1999); Karl E. Johnson, "Police-Black Community Relations in Postwar Philadelphia: Race and Criminalization in Urban Social Spaces, 1945-1960," Journal of African American History 89 (Spring 2004): 118-34; Dwight D. Watson, Race and the Houston Police Department, 1930-1990: A Change Did Come (College Station: Texas A\&M University Press, 2005); Matthew Countryman, Up South: Civil Rights and Black Power in Philadelphia (Philadelphia: University of Pennsylvania Press, 2005); Patrick D. Jones, The Selma of the North: Civil Rights Insurgency in Milwaukee (Cambridge: Harvard University Press, 2009); Khalil Gibran Muhammad, The Condemnation of Blackness: Race, Crime, and the Making of Modern Urban America (Cambridge: Harvard University Press, 2010); Donna Murch, Living for the City: Migration, Education, and the Rise of the Black Panther Party in Oakland, California (Chapel Hill: University of North Carolina Press, 2010); Leonard N. Moore, Black Rage in New Orleans: Police Brutality and African American Activism from World War II to Hurricane Katrina (Baton Rouge: Louisiana State University Press, 2010); Heather Ann Thompson, "Why Mass Incarceration Matters: Rethinking Crisis, Decline, and Transformation in Postwar American History," Journal of American History 97 (December 2010): 703-34; Themis Chronopoulos, Spatial Regulation in New York City: From Urban Renewal to Zero Tolerance (New York: Routledge, 2011); Simon Ezra Balto, “"Occupied Territory': Police Repression and Black Resistance in Postwar Milwaukee, 1950-1968," Journal of African American History 98 (Spring 2013): 229-52; Tera Agyepong, "In the Belly of the Beast: Black Policemen Combat Police Brutality in Chicago, 1968-1983," Journal of African American History 98 (Spring 2013): 253-76.

9. Martha Biondi, To Stand and Fight: The Struggle for Civil Rights in Postwar New York City (Cambridge: Harvard University Press, 2003), 70.

10. Clarence Taylor, "Race, Class, and Police Brutality in New York City: The Role of the Communist Party in the Early Cold War Years," Journal of African American History 98 (Spring 2013): 205-28.

11. Marilynn Johnson, Street Justice: A History of Police Violence in New York City (Boston: Beacon Press, 2003).

12. Johnson, Street Justice, 210-11; William L. Patterson, ed., We Charge Genocide: The Historic Petition to the United Nations for Relief from a Crime of the United States Government against the Negro People (New York: Civil Rights Congress, 1951), 98; Roy Wilkins, Assistant Secretary, NAACP to Arthur Wallander, Police Commissioner, NYPD, August 14, 1947, National Association for the Advancement of Colored People (hereafter, NAACP) Papers, Part 8, Group II, Series B, Legal File: Police Brutality, Library of Congress; Marian Wynn Perry to Franklin H. Williams, September 10, 1947, NAACP Papers, Part 8, Group II, Series B, Legal File: Police Brutality, Library of Congress.

13. Patterson, We Charge Genocide, 59, 75, 104; Justin N. Feldman, Legal Assistance Director, The American Veterans Committee, Inc., to Frank Williams, NAACP, May 21, 1946, NAACP Papers, Part 8, Group II, Series B, Legal File: Police Brutality, Library of Congress; Robert L. Carter, Assistant Special Counsel, NAACP to Arthur W. Wallander, June 12, 1946, NAACP Papers, Part 8, Group II, Series B, Legal File: Police Brutality, Library of Congress; Sidney R. Katz to Will Maslow, "Subject: The Killing of a Negro in Harlem Two Weeks Ago," July 30, 1946, NAACP Papers, Part 8, Group II, Series B, Legal File: Police Brutality, Library of Congress; Franklin H. Williams, Assistant Special Counsel, NAACP to Police Commissioner Wallander, August 9, 1946, NAACP Papers, Part 8, Group II, Series B, Legal File: Police Brutality, Library of Congress; Leon A. Ransom, Chairman Legal Committee, DC Branch, NAACP to Robert Carter and Marian Wynn Perry, NAACP, March 9, 1947, NAACP Papers, Part 8, Group II, Series B, Legal File: Police Brutality, Library of Congress; Elvita Manning to Police Commissioner Wallander, December 11, 1947, NAACP Papers, Part 8, Group II, Series B, Legal File: Police Brutality, Library of Congress; Franklin H. Williams, Assistant Special Council, NAACP to Commissioner Arthur Wallander, March 22, 1948, NAACP Papers, Part 8, Group II, Series B, Legal File: Police Brutality, Library of Congress; Charles A. Levy, Executive Secretary, New York Branch of the NAACP to Constance Baker Motley, NAACP Legal and Educational Defense Fund, Inc., February 3, 1949, NAACP Papers, Part 8, Group II, Series B, Legal File: Police Brutality, 
Library of Congress; Franklin H. Williams, Assistant Special Council, NAACP to Elvita Manning, President, Far Rockaway Branch, NAACP, June 20, 1949, NAACP Papers, Part 8, Group II, Series B, Legal File: Police Brutality, Library of Congress; Alexander M. Campbell, Assistant Attorney General, Department of Justice to Franklin H. Williams, November 18, 1949, NAACP Papers, Part 8, Group II, Series B, Legal File: Police Brutality, Library of Congress; Clare Rodney, Manhattan Executive Secretary, New York State Civil Rights Congress to Friend, November 14, 1949, NAACP Papers, Part 8, Group II, Series B, Legal File: Police Brutality, Library of Congress; Franklin H. Williams to Darwin Telesford, Chairman, New York Branch Legal Redress Committee, November 25, 1949 , NAACP Papers, Part 8, Group II, Series B, Legal File: Police Brutality, Library of Congress.

14. Guy R. Brewer to Walter White, August 8, 1946, NAACP Papers, Part 8, Group II, Series B, Legal File: Police Brutality, Library of Congress; John H. Johnson, Police Chaplain to Walter White, November 5, 1947, NAACP Papers, Part 8, Group II, Series B, Legal File: Police Brutality, Library of Congress; Benjamin J. Davis to Rev. John H. Johnson, December 9, 1947, NAACP Papers, Part 8, Group II, Series B, Legal File: Police Brutality, Library of Congress; Citizens Committee to End Police Brutality, "Press Release," February 14, 1948, NAACP Papers, Part 8, Group II, Series B, Legal File: Police Brutality, Library of Congress; Jawn Sandifer, President and Herbert Hill, Chairman of Committee, New York Branch of the NAACP to Gloster Current, NAACP, April 6, 1948, NAACP Papers, Part 8, Group II, Series B, Legal File: Police Brutality, Library of Congress; Madison S. Jones, Jr., Administrative Assistant to Jawn Sandifer, President, New York Branch NAACP, June 7, 1948, NAACP Papers, Part 8, Group II, Series B, Legal File: Police Brutality, Library of Congress; Constance Baker Motley, "Memorandum to Mr. Marshall," August 25, 1949, NAACP Papers, Part 8, Group II, Series B, Legal File: Police Brutality, Library of Congress; Joint Committee of New York City Branches of the NAACP, "To: All Branches, Youth Councils, College Chapters in the N.Y.C. Area," September 23, 1949, NAACP Papers, Part 8, Group II, Series B, Legal File: Police Brutality, Library of Congress; Patterson, We Charge Genocide.

15. Johnson, Street Justice, 222-24.

16. Ibid., 225.

17. Johnson, Street Justice, 222-27; Adam Clayton Powell, Jr., Adam by Adam: The Autobiography of Adam Clayton Powell, Jr. (New York: Dial Press, 1971), 139-45; Barbara Ransby, "Cops, Schools, and Communism: Local Politics and Global Ideologies-New York City in the 1950s," in Civil Rights in New York City: From World War II to the Giuliani Era, ed. Clarence Taylor (New York: Fordham University Press, 2011), 40-41; Wil Haygood, King of the Cats: The Life and Times of Adam Clayton Powell, Jr. (New York: Houghton Mifflin, 1993), 180-81.

18. Johnson, Street Justice, 227.

19. Arthur W. Wallander to William O'Dwyer, July 2, 1946, William O'Dwyer Administration Subject Files, Box 36, Folder 328, Municipal Archives of the City of New York (hereafter, MACNY); J. Edgar Hoover to William O'Dwyer, July 25, 1949, O’Dwyer Administration Subject Files, Box 36, Folder 330, MACNY; William P. O'Brien to William O'Dwyer, August 12, 1949, O'Dwyer Administration Subject Files, Box 36, Folder 330, MACNY; Richard S. Childs to William O’Dwyer, March 20, 1950, O’Dwyer Administration Subject Files, Box 36, Folder 330, MACNY; Commanding Officer, Borough of Bronx to Chief Inspector, "Report RE: Anonymous Complaint That Police Dept. Is Permitting Bronx and East Side White Racketeers to Continue Operate Numbers Gangs in Harlem," September 22, 1947, O’Dwyer Administration Departmental Files, Box 41, Folder 372, MACNY.

20. A. Everett Leonard, "Crime Records in Police Management: New York City” (Mayor's Committee on Management Survey, Subcommittee on Police, November 1951), Vincent R. Impellitteri Administration Subject Files, Box 25, Folder 237, MACNY.

21. One of the People to Thomas E. Dewey, July 19, 1947, O’Dwyer Administration Subject Files, Box 36, Folder 329, MACNY; Foreman to Nathan R. Sobel, "Presentment of the August, 1947 Grand Jury of Kings County in the Matter of Investigation of Horse Racing, Betting, and Bookmaking” (August 1947), O’Dwyer Administration Subject Files, Box 36, Folder 329, MACNY; William O'Dwyer to Lee B. Mailler et al., January 10, 1950, O’Dwyer Administration Subject Files, Box 36, Folder 338, MACNY; Leo Egan, "Dewey Holds City Can Bar Gambling," New York Times, January 18, 1950, 1; Raymon H. Chadeayne to Vincent R. Impellitteri, September 25, 1950, Impellitteri Administration Subject Files, Box 24, Folder 229, MACNY; Edward Corsi, Telegram to Mayor Vincent Impellitteri, September 21, 1950, Impellitteri Administration Departmental Files, Box 3, Folder 59, MACNY. 
22. George Walsh, Public Enemies: The Mayor, the Mob, and the Crime That Was (New York: Norton, 1980); James Lardner and Thomas Reppetto, NYPD: A City and Its Police (New York: Henry Holt and Co., 2000), 261-65; Johnson, Street Justice, 222-23; James A. Delehanty, "In the Matter of Charges against Walter D. Barbuck and Thirty-Three Others," February 21, 1953, Impellitteri Administration Departmental Files, Box 32, Folder 416, MACNY; John F. X. Finn to Vincent R. Impellitteri, June 8, 1953, Impellitteri Administration Departmental Files, Box 33, Folder 417, MACNY.

23. Bruce Smith, "The New York Police Survey: Prepared for the Mayor's Committee on Management Survey" (New York: Institute of Public Administration, 1952), Impellitteri Administration Subject Files, Box 82, Folder 960, MACNY.

24. Lazarus Joseph to Vincent R. Impellitteri, October 20, 1952, Impellitteri Administration Subject Files, Box 82, Folder 960, MACNY; Charles G. Bennett, "Monaghan Assails Report on Police," New York Times, November 25, 1952, 1.

25. Milton W. Bergerman to Robert F. Wagner, Telegram, February 10, 1954, Robert F. Wagner Administration Departmental Files, Box 100, Folder 1184, MACNY.

26. Patrolmen's Benevolent Association of the City of New York, "Resolution on 'Shoo-Fly' System," February 9, 1954, Wagner Administration Departmental Files, Box 100, Folder 1184, MACNY; Lardner and Reppetto, NYPD, 191-212; "Wagner Affirms Support of Adams in Police Dispute," New York Times, February 16, 1954, 1.

27. R. A. Dougherty, "For Immediate Release," March 16, 1954, Wagner Administration Departmental Files, Box 100, Folder 1184, MACNY; Bureau of Public Relations, Police Department, "Press Release," March 30, 1954, Wagner Administration Departmental Files, Box 100, Folder 1184, MACNY; Bureau of Public Relations, Police Department, "Press Release," April 9, 1954, Wagner Administration Departmental Files, Box 100, Folder 1184, MACNY; Bureau of Public Relations, Police Department, "Press Release," April 29, 1954, Wagner Administration Departmental Files, Box 100, Folder 1183, MACNY; Bureau of Public Relations, Police Department, "Remarks of Police Commissioner F. W. H. Adams, at Annual Dinner, Citizens Union, Wednesday, May 19, 1954, at Hotel Biltmore," May 19, 1954, Wagner Administration Departmental Files, Box 100, Folder 1183, MACNY; F. W. H. Adams to Robert F. Wagner, June 2, 1954, Wagner Administration Departmental Files, Box 100, Folder 1182, MACNY; Community Relations, Police Department, "Press Release," September 24, 1954, Wagner Administration Departmental Files, Box 100, Folder 1186, MACNY; Community Relations, Police Department, "Press Release," November 4, 1954, Wagner Administration Departmental Files, Box 100, Folder 1186, MACNY; F. W. H. Adams to Henry Epstein, "Re. Report No. MR-10891-3/26/54," December 7, 1954, Wagner Administration Departmental Files, Box 100, Folder 1188, MACNY; Community Relations, Police Department, "Police Commissioner's Remarks, Trial Room, to Representatives of Business and Trade Groups, Relative to Christmas Gratuities, Monday, December 6, 1954, at 3pm," December 10, 1954, Wagner Administration Departmental Files, Box 100, Folder 1185, MACNY; Community Relations, Police Department, December 29, 1954, No. 129, Wagner Administration Departmental Files, Box 100, Folder 1185, MACNY.

28. Community Relations, Police Department, "Remarks of Police Commissioner F. W. H. Adams, Radio and Television, Sunday, July 24th, 1955," July 22, 1955, No. 59, Wagner Administration Departmental Files, Box 101, Folder 1190, MACNY.

29. Community Relations, Police Department, February 3, 1955, No. 10, Wagner Administration Departmental Files, Box 100, Folder 1230, MACNY; Editor, "Blunt Facts," Spring 3100 25(6) (June 1954); Office of the Mayor, "Statement of Mayor Robert F. Wagner," November 28, 1954, Wagner Administration Departmental Files, Box 100, Folder 1185, MACNY; Community Relations, Police Department, "Remarks Made by His Honor the Mayor, Robert F. Wagner, at Swearing in Ceremonies of 740 Probationary Patrolmen and 4 Probationary Policewomen, February 1st, 1955," February 2, 1955, No. 9, Wagner Administration Departmental Files, Box 105, Folder 1230, MACNY.

30. "Kennedy's Policy Speech to Police Officers," New York Times, August 9, 1955, 18; Lardner and Reppetto, NYPD, 250.

31. "Police Shake-Up Hits Police Force," New York Times, August 17, 1955, 24; "Police in Brooklyn By-passed in Raid," New York Times, August 19, 1955, 39; "Kennedy, on a Surprise Tour Finds Detective Heads Absent," New York Times, November 9, 1955, 35; George Blumenthal to Stephen P. Kennedy, Sergeants Benevolent Association, November 30, 1955, Wagner Administration Departmental Files, 
Box 100, Folder 1189, MACNY; “Kennedy Stiffens Detectives' Tests," New York Times, February 16, 1956, 31; "Detectives Filing Reports on Work," New York Times, July 4, 1954, 21.

32. Community Relations, Police Department, "Remarks of Police Commissioner F.W.H. Adams, Radio and Television: A Report on Operation 25," November 28, 1954, No. 116, Wagner Administration Departmental Files, Box 100, Folder 1185, MACNY; Community Relations, Police Department, "Remarks of Police Commissioner Stephen P. Kennedy at a Meeting of the Precinct Youth Councils in the Line-Up Room, Manhattan Police Headquarters," August 16, 1956, No. 103; Wagner Administration Departmental Files, Box 105, Folder 1231, MACNY; Community Relations, Police Department, "Remarks of Police Commissioner Stephen P. Kennedy at the Worldwide Conference of Senior Supervising and Staff Chaplains in the United States Air Force, at the Sheraton-Park Hotel, Washington, DC," February 12, 1957, No. 17, Wagner Administration Departmental Files, Box 105, Folder 1233, MACNY; Community Relations, Police Department, "Immediately," February 25, 1957, Wagner Administration Departmental Files, Box 105, Folder 1238, MACNY; Homer Bigart, "All Rookie Police Ordered on Beat," New York Times, March 21, 1958, 1; Community Relations, Police Department, "Immediately," May 18, 1959, No. 31, Wagner Administration Departmental Files, Box 106, Folder 1240, MACNY; Community Relations, Police Department, "Immediately," November 30, 1959, No. 79, Wagner Administration Departmental Files, Box 106, Folder 1241, MACNY; Community Relations, Police Department, "For Release," January 27, 1962, No. 6, Wagner Administration Departmental Files, Box 105, Folder 1234, MACNY.

33. James L. Hicks, "Riot Threat as Cops Beat Moslem," New York Amsterdam News, May 4, 1957, 1.

34. Ibid.

35. Ibid.

36. Editorial, "Police Brutality," New York Amsterdam News, May 4, 1957, 8; Bruce Perry, Malcolm: The Life of a Man who Changed Black America (Barrytown: Station Hill, 1991), 163-6; Manning Marable, Malcolm X: A Life of Reinvention (New York: Allen Lane, 2011), 127-29.

37. "Harlem Tensions Cited in Flare-Up," New York Times, July 15, 1959, 13.

38. Al Nall, "Notarized Riot Statement: 'The Cop Dragged Her Out by Her Hair . . .," New York Amsterdam News, July 18, 1959, 1.

39. Peter Kihss, “4 Negro Areas Get Extra Police Units,” New York Times, July 16, 1959, 1.

40. "Harlem Minister Backs Police Commissioner," New York Amsterdam News, August 1, 1959, 4.

41. "NAACP Official Tells What Causes Tensions," New York Amsterdam News, August 22, 1959, 2.

42. Kihss, "4 Negro Areas Get Extra Police Units," 1.

43. Ibid.

44. "Harlem Cops Under Probe on Gambling," New York Amsterdam News, December 22, 1956, 1; "Numbers 'Roundup' Nabs Harlemites," New York Amsterdam News, June 22, 1957, 1; “Cops Continue Numbers Drive, 191 Arrested," New York Amsterdam News, May 17, 1958, 6; George Barner and James Booker, "Gamblers on the Run," New York Amsterdam News, March 14, 1959, 1; "Grand Jury Report Hits Harlem Police," New York Amsterdam News, March 28, 1959, 18.

45. Charles V. Hamilton and Adam Clayton Powell, Jr., The Political Biography of an American Dilemma (New York: Atheneum, 1991), 430-31; Peter Kihss, "Powell Sees Bias in Policy Arrests," New York Times, January 4, 1960, 9; Emanuel Perlmuttter, "Powell Charges Touch Off Raids," New York Times, January 6, 1960, 1; Haygood, King of the Cats, 252-55; Powell, Adam by Adam, 145-58; Peter Reuter and Jonathan Rubinstein, Illegal Gambling in New York: A Case Study in the Operation, Structure, and Regulation of an Illegal Market (Washington, DC: U.S. Department of Justice, 1982).

46. Charles G. Bennett, "Kennedy Bars Harlem Bid for a Negro Police Deputy," New York Times, February $6,1960,1$.

47. James Baldwin, Nobody Knows My Name: More Notes of a Native Son (New York: Vintage, 1993), $65-66$.

48. Robert M. Fogelson, Big City Police (Cambridge: Harvard University Press, 1977), 197-98.

49. Fogelson, Big City Police, 197-98; Mark H. Maier, City Unions: Managing Discontent in New York City (New Brunswick: Rutgers University Press, 1987), 94.

50. Maier, City Unions, 44-50 and 94-95; Themis Chronopoulos, "The Lindsay Administration and the Sanitation Crisis of New York City, 1966-1973," Journal of Urban History 40 (November 2014): 1149-50; Community Relations, Police Department, "Statement of Police Commissioner Stephen 
P. Kennedy Regarding the Demand of the Patrolmen's Benevolent Association for a Check-Off of P.B.A. Dues," August 20, 1959, Wagner Administration Departmental Files, Box 106, Folder 1241, MACNY; Community Relations, Police Department, "Statement by Police Commissioner Stephen P. Kennedy," October 21, 1960, No. 75, Wagner Administration Departmental Files, Box 106, Folder 1242, MACNY; Moriarity v. Kennedy, 20 Misc. 2d 593; 192 N.Y.S.2d 32; 1959 N.Y. Misc. (1959); Patrolmen's Benevolent Association v. Wagner, 8 A.D.2d 369; 187 N.Y.S.2d 809; 1959 N.Y. App. Div. (1959); Patrolmen's Benevolent Association v. Wagner, 7 N.Y.2d 813; 164 N.E.2d 715; 196 N.Y.S.2d 694; 1959 N.Y. (1959).

51. Maier, City Unions, 95; Paul Crowell, "60 to 70\% of City's Policemen Reported Holding Extra Jobs," New York Times, October 17, 1960, 1; Office of the Mayor, "For Immediate Release," October 26, 1960, Wagner Administration Departmental Files, Box 102, Folder 1200, MACNY; Joseph C. Ingraham, "Police Discipline Leader of P.B.A. in Ticket Revolt," New York Times, October 27, 1960, 1; "Parking Tickets Rise 132\% Here," The New York Times, October 30, 1960, 1; "Crackdown Puts Police on Beats," New York Times, October 31, 1960, 1; Lardner and Reppetto, NYPD, 252;"Police Must Sign Extra-Job Denial," New York Times, November 11, 1960, 25; "P.B.A. Delegates Transfer Session to Cassese's Home," New York Times, November 16, 1960, 1; Guy Passant, "Police Head Rips P.B.A. Card in Two," New York Times, November 17, 1960, 1; Flood v. Kennedy, 12 N.Y.2d 345; 190 N.E.2d 13; 239 N.Y.S.2d 665; 1963 N.Y. (1963).

52. Office of the President of the Council, "For Immediate Release," September 28, 1960, Wagner Administration Departmental Files, Box 102, Folder 1200, MACNY; Arthur Gelb, "Charges of Police Corruption Made by Citizens' Group Here," New York Times, November 14, 1960, 1; Lardner and Reppetto, NYPD, 252; George Barrett, "Murphy Is Named," The New York Times, February 23, 1961, 1.

53. Maier, City Unions, 95; Francis J. M. Robb, "Establishment of Procedures for the Presentation, Processing and Review of Grievances, Dept. Dir. No. 50," March 14, 1961, Wagner Administration Departmental Files, Box 102, Folder 1201, MACNY; Patrolmen's Benevolent Association, "Resolution," September 13-16, 1962, Wagner Administration Departmental Files, Box 231, Folder 2915, MACNY; Robert F. Wagner to Michael J. Murphy, "Executive Memorandum," March 29, 1963, Wagner Administration Departmental Files, Box 104, Folder 1220, MACNY.

54. The Nation of Islam was also quite successful, though its numbers could not match those of CORE.

55. Arthur A. Stone to Cynthia K. Homire, February 23, 1960, The Papers of CORE, 1941-1967, Series 5, Subseries 70, Butler Library, Columbia University.

56. Sugrue, Sweet Land of Liberty, 400-14; Johnson, Street Justice, 216-19 and 229-32; William P. Brown to James Farmer, February 20, 1962, The Papers of CORE, 1941-1967, Series 1, Subseries 63, Butler Library, Columbia University; Jim McCain to Mary Hamilton, "Bronx CORE," March 27, 1962, The Papers of CORE, 1941-1967, Series 5, Subseries 372, Butler Library, Columbia University; Alan Gartner to CORE, 38 Park Row, "Subject: Police Relations," June 21, 1963, The Papers of CORE, 1941-1967, Series 5, Subseries 300, Butler Library, Columbia University; Bronx C.O.R.E., "Police Brutality Case of Jesse Roberts," March 6, 1964, The Papers of CORE, 1941-1967, Series 5, Subseries 69, Butler Library, Columbia University; Herbert Callender to Nelson Rockefeller et al., March 13, 1964, The Papers of CORE, 1941-1967, Series 5, Subseries 300, Butler Library, Columbia University; August Meier and Elliott Rudwick, CORE: A Study in the Civil Rights Movement (Urbana: University of Illinois Press, 1975), 230-31, 237-37; Louis E. Lomax, The Negro Revolt (London: Hamish Hamilton, 1963), 101-20.

57. Shapiro and Sullivan, Race Riots: New York 1964, 31.

58. Kenneth B. Clark, Dark Ghetto: Dilemmas of Social Power (London: Victor Gollancz Limited, 1965), 14, 86, and 92; Shapiro and Sullivan, Race Riots: New York 1964, 30-31; Michael F. Armstrong, They Wished They Were Honest: The Knapp Commission and New York City Police Corruption (New York: Columbia University Press, 2012); Robert M. Fogelson, "From Resentment to Confrontation: The Police, the Negroes, and the Outbreak of the Nineteen-Sixties Riots," Political Science Quarterly 83 (June 1968): 217-47.

59. Meier and Rudwick, CORE, 250.

60. Congress of Racial Equality (Brooklyn), "Police Brutality," November 12, 1963, The Papers of CORE, 1941-1967, Series 1, Subseries 12, Butler Library, Columbia University; Brian Purnell, Fighting Jim Crow in the County of Kings: The Congress of Racial Equality in Brooklyn (Lexington: University of Kentucky Press, 2013), 209-47, 249-78; Johnson, Street Justice, 229-31; Meier and 
Rudwick, CORE, 250; Arthur I. Waskow, From Race Riot to Sit-In, 1919 and the 1960s: A Study in the Connections between Conflict and Violence (Gloucester: Peter Smith, 1975), 245-46; Peter Eisenstadt, Rochdale Village: Robert Moses, 6,000 Families, and New York City's Great Experiment in Integrated Housing (Ithaca: Cornell University Press, 2010), 83-105. Sugrue, Sweet Land of Liberty, 328-29, Mandi Isaacs Jackson, “Harlem's Rent Strike and Rat War: Representation, Housing Access and Tenant Resistance in New York, 1958-1964," American Studies 47 (Spring 2006): 43-79; News From NAACP, "Demonstrations Pinpoint Bias in New York City," July 27, 1963, NAACP Papers, Part 20, Group III, Series A, Administrative File: General Office File - Reprisals, Library of Congress; Marvin Moses Karpatkin to Carl Rachlin, Esq., August 21, 1963, The Papers of CORE, 1960-1976, Part 3, Series C, Reel 4, University of Cambridge; George Schiffer to Carl Rachlin, Esq., June 4, 1965, The Papers of CORE, 1960-1976, Part 3, Series C, Reel 30, University of Cambridge.

61. Community Relations, Police Department, City of New York "Remarks of Police Commissioner Michael J. Murphy at the 46th Annual Communion Breakfast of the Police Department Holy Name Society, Manhattan, Bronx, and Richmond, Sunday, March 15, 1964, at New York Hilton Hotel," No. 21, March 16, 1964, The Papers of CORE, 1960-1976, Part 3, Series C, Reel 30, University of Cambridge.

62. Ibid.

63. Lomax, The Negro Revolt, 59-60.

64. Abu-Lughod, Race, Space, and Riots, 169-71; Truman Nelson, The Torture of Mothers (Boston: Beacon Press, 1968).

65. "Police Ask Your Help in Keeping Order," New York Amsterdam News, April 20, 1963, 4.

66. Jervis Anderson in Harlem: The Great Black Way, 1900-1950 (London: Orbis Publishing, 1982) claims that Seventh Avenue was the main street of Harlem. Seventh Avenue was certainly the widest street in central Harlem, the route of most major parades, and the location of many important institutions. However, 125th Street was the most popular commercial location.

67. Neil Hickey and Ed Edwin, Adam Clayton Powell and the Politics of Race (New York: Fleet, 1965), 150-51, 164-65, 236-37; Marable, Malcolm X, 216; LeRoi Jones, Home: Social Essays (London: MacGibbon \& Kee, 1968), 92-93, 97-104; Peniel E. Joseph, Waiting 'Til the Mignight Hour: A Narrative History of Black Power in America (New York: Henry Holt and Co., 2006), 13-14; Haygood, King of the Cats, 262; David Emblidge, "Rallying Point: Lewis Michaux's National Memorial African Bookstore," Publishing Research Quarterly 24 (December 2008): 267-76.

68. Flamm, "New York's Night of Birmingham Horror," 81-97.

69. Lardner and Reppetto, NYPD, 252-55.

70. Social Action Committee, The Community Church of New York, "Re: Civilian Complaint Review Board," August 10, 1965, The Papers of CORE, 1960-1976, Part 3, Series C, Reel 7, University of Cambridge.

71. Vincent J. Cannato, The Ungovernable City: John Lindsay and His Struggle to Save New York (New York: Basic Books, 2001), 157.

72. Ibid.

73. Office of the Mayor, "Address of Mayor Robert F. Wagner on Safety in the Streets," April 22, 1965, Wagner Administration Departmental Files, Box 104, Folder 1225, MACNY.

74. Richard Witkin, "CORE to Oppose Wagner in Fall," New York Times, April 8, 1965, 1.

75. Jack Roth, "Powell Predicts Wagner Victory," New York Times, April 28, 1965, 32.

76. Flamm, "New York's Night of Birmingham Horror," 81-97; Cannato, The Ungovernable City, 15657; Ruth Cowan, "The New York City Civilian Review Board Referendum of November 1966: A Case Study of Mass Politics (PhD diss., New York University, 1970), 36; Office of the Mayor, "For Release," August 12, 1964, Wagner Administration Departmental Files, Box 104, Folder 1223, MACNY.

77. Charles R. Morris, The Cost of Good Intentions: New York City and the Liberal Experiment, 19601975 (New York: Norton, 1980), 30.

\section{Author Biography}

Themis Chronopoulos is a lecturer in American History and Culture at the University of East Anglia in Norwich, United Kingdom. He is the author of Spatial Regulation in New York City: From Urban Renewal to Zero Tolerance (New York: Routledge, 2011). He is currently writing a book titled When the Government Disappears: Inadequate Municipal Service Delivery and the Decline of New York City, 1945-1981. 